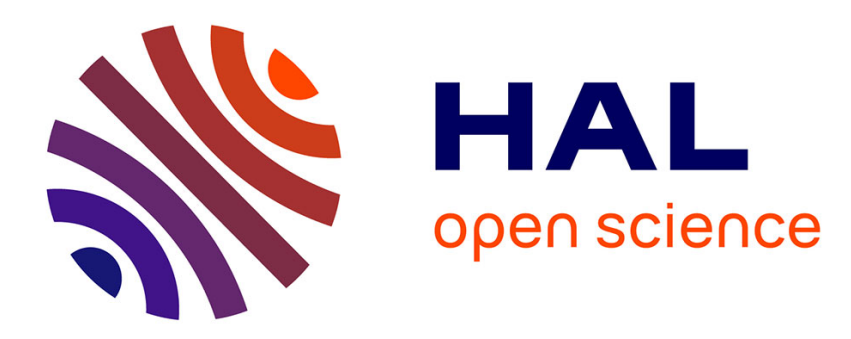

\title{
Oscillatory control of insulin secretion
}

Anders Tengholm, Erik Gylfe

\section{To cite this version:}

Anders Tengholm, Erik Gylfe. Oscillatory control of insulin secretion. Molecular and Cellular Endocrinology, 2008, 297 (1-2), pp.58. 10.1016/j.mce.2008.07.009 . hal-00532053

\section{HAL Id: hal-00532053 \\ https://hal.science/hal-00532053}

Submitted on 4 Nov 2010

HAL is a multi-disciplinary open access archive for the deposit and dissemination of scientific research documents, whether they are published or not. The documents may come from teaching and research institutions in France or abroad, or from public or private research centers.
L'archive ouverte pluridisciplinaire HAL, est destinée au dépôt et à la diffusion de documents scientifiques de niveau recherche, publiés ou non, émanant des établissements d'enseignement et de recherche français ou étrangers, des laboratoires publics ou privés. 


\section{Accepted Manuscript}

Title: Oscillatory control of insulin secretion

Authors: Anders Tengholm, Erik Gylfe

PII:

S0303-7207(08)00292-X

DOI: doi:10.1016/j.mce.2008.07.009

Reference: $\quad$ MCE 6921

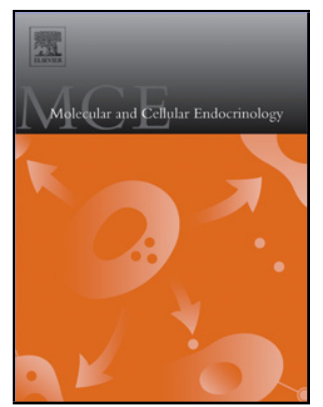

To appear in: $\quad$ Molecular and Cellular Endocrinology

Received date: $\quad 28-2-2008$

Revised date: $\quad 30-5-2008$

Accepted date: $\quad 10-7-2008$

Please cite this article as: Tengholm, A., Gylfe, E., Oscillatory control of insulin secretion, Molecular and Cellular Endocrinology (2007), doi:10.1016/j.mce.2008.07.009

This is a PDF file of an unedited manuscript that has been accepted for publication. As a service to our customers we are providing this early version of the manuscript. The manuscript will undergo copyediting, typesetting, and review of the resulting proof before it is published in its final form. Please note that during the production process errors may be discovered which could affect the content, and all legal disclaimers that apply to the journal pertain. 


\section{Oscillatory control of insulin secretion}

\section{Anders Tengholm and Erik Gylfe}

Department of Medical Cell Biology, Biomedical Centre, Box 571, SE-751 23 Uppsala, Sweden

Key words: Insulin secretion, oscillations, metabolism, $\mathrm{Ca}^{2+}$, cAMP, phospholipase C, $\mathrm{PIP}_{2}$, PI3-kinase, $\mathrm{PIP}_{3}$

Correspondence:

Anders Tengholm

Department of Medical Cell Biology

Uppsala University

Biomedical Centre Box 571

SE-75123 Uppsala

Sweden

Phone: +46-18-4714481

Fax: +46-18-4714059

E-mail: anders.tengholm@mcb.uu.se 


\begin{abstract}
Pancreatic $\beta$-cells possess an inherent ability to generate oscillatory signals that trigger insulin release. Coordination of the secretory activity among $\beta$-cells results in pulsatile insulin secretion from the pancreas, which is considered important for the action of the hormone in the target tissues. This review focuses on the mechanisms underlying oscillatory control of insulin secretion at the level of the individual $\beta$-cell. Recent studies have demonstrated that oscillations of the cytoplasmic $\mathrm{Ca}^{2+}$ concentration are synchronized with oscillations in $\beta$-cell metabolism, intracellular cAMP concentration, phospholipase $\mathrm{C}$ activity and plasma membrane phosphoinositide lipid concentrations. There are complex interdependencies between the different messengers and signalling pathways that contribute to amplitude regulation and shaping of the insulin secretory response to nutrient stimuli and neurohormonal modulators. Several of these pathways may be important pharmacological targets for improving pulsatile insulin secretion in type 2 diabetes.
\end{abstract}

\title{
1. Pulsatile insulin secretion
}

Since insulin is the only blood glucose-lowering hormone, its secretion is essential for glucose homeostasis, and disturbances are associated with glucose intolerance and diabetes. Glucose is the major stimulus for insulin release but secretion is enhanced also by other nutrients and is under stimulatory and inhibitory control by hormones and neurotransmitters. Although the external factors are essential determinants of insulin secretion, there are also input-independent variations in hormone release. Regular oscillations of the circulating insulin concentrations in normal subjects consequently occur without accompanying changes 
in plasma glucose and reflect a pacemaker function of the pancreas (Lang et al., 1981; Matthews et al., 1983a). Studies in normal subjects with suppressed endogenous insulin secretion and diabetic patients have indicated that less insulin is required to maintain normoglycaemia if the hormone is infused in an oscillatory manner compared to a constant rate (Matthews et al., 1983b; Bratusch-Marrain et al., 1986; Matthews et al., 1987; Paolisso et al., 1988a; Paolisso et al., 1988b). The better efficiency of oscillatory insulin delivery is probably due to higher expression of insulin receptors (Goodner et al., 1988). Interestingly, this characteristic insulin pattern is early deteriorated in patients with type 2 diabetes (Lang et al., 1981; Matthews, 1987) and their close relatives (O'Rahilly et al., 1988). Therefore, loss of insulin oscillations may contribute to insulin resistance that needs to be compensated by hypersecretion of the hormone. The increased insulin demand may exhaust the pancreatic $\beta$-cells and cause overt type 2 diabetes in susceptible individuals.

The insulin oscillations are generated by pulsatile secretion from the pancreas. The oscillations are most prominent in the portal vein, which delivers blood from the pancreas to the liver. Measurements in the portal vein of dogs and humans have indicated that virtually all insulin $(>70-75 \%)$ is released in a pulsatile fashion (Pørksen et al., 1995; Pørksen et al., 1997). Early estimates of pulse intervals are somewhat variable due to technical limitations but later data indicate a periodicity of 4-6 min in humans (Storch et al., 1993; Pørksen et al., 1997; Ritzel et al., 2001) and dogs (Pørksen et al., 1996). The insulin-releasing $\beta$-cells are located in about 1 million islets of Langerhans distributed within the $25 \mathrm{~cm}$ long human pancreas. It is evident that pulsatile secretion requires a formidable coordination of the secretory activity among islets and $\beta$-cells. Since this coordination occurs in the absence of external neuronal input to the pancreas but can be temporarily disrupted by neurotransmitters, 
it was early suggested to involve coordination by intrapancreatic neurons (Stagner et al., 1980). Later experiments confirmed that pulsatile secretion is prevented by neural blockade (Stagner and Samols, 1985a; Gylfe et al., 2000). However, the neurons involved do not seem to be adrenergic or cholinergic (Stagner and Samols, 1985b). Studies of the synchronization of $\mathrm{Ca}^{2+}$ signalling among dispersed $\beta$-cells by humoral factors have led to proposals that ATP (Grapengiesser et al., 1999; Grapengiesser et al., 2004; Hellman et al., 2004; Grapengiesser et al., 2005) and/or the gases NO (Grapengiesser et al., 1999; Grapengiesser et al., 2001) and CO (Lundquist et al., 2003) released from neurons act to coordinate pulsatile insulin secretion (see below).

Insulin secretion remains pulsatile in isolated individual pancreatic islets from mice (Bergsten and Hellman, 1993b; Bergsten and Hellman, 1993a; Gilon et al., 1993; Bergsten et al., 1994; Bergsten, 1995; Gilon and Henquin, 1995) and humans (Hellman et al., 1994) with a dominating frequency similar to that of secretion from the pancreas. The rhythmic variations in secretion from islets are synchronized with oscillations of the cytoplasmic $\mathrm{Ca}^{2+}$ concentration ([Ca $\left.{ }^{2+}\right]_{\mathrm{i}}$; (Gilon et al., 1993; Bergsten et al., 1994; Bergsten, 1995; Gilon and Henquin, 1995)), which is the most important trigger of insulin release (see below). Studying $\left[\mathrm{Ca}^{2+}\right]_{\mathrm{i}}$ signalling in clusters of mouse $\beta$-cells exposed to intermediate stimulating concentrations of glucose some adjacent cells were oscillating in synchrony whereas others were silent (Gylfe et al., 1991). Further increase of the glucose concentration resulted in spreading of the synchronized oscillations to previously silent cells, and it was possible to follow signal propagation between the cells. This experiment illustrates the importance of $\beta$ cell recruitment and intercellular coupling for glucose regulation of the insulin pulse amplitudes. It has been known for a long time that $\beta$-cells are electrically coupled by gap 
junctions, and the dominating intercellular channel was later identified as connexin 36 (Ravier et al., 2005). Opinions differ about the size of electrically coupled $\beta$-cell clusters within pancreatic islets ranging from relatively few cells to a functional syncytium involving all $\beta$-cells (Bavamian et al., 2007). These differences may perhaps be explained by variations in coupling at different functional states. However, spreading of the depolarization underlying rise of $\left[\mathrm{Ca}^{2+}\right]_{\mathrm{i}}$ (see below) by gap junctional coupling is certainly the most important explanation for synchronization of pulsatile insulin release between $\beta$-cells in the islets of Langerhans.

The kinetics of insulin secretion can be studied with relatively good time resolution from individual pancreatic islets using traditional immunoassays. Unfortunately, such techniques are not sufficiently sensitive to characterize the kinetics of secretion from individual $\beta$-cells. Patch clamp recordings of changes in plasma membrane capacitance with fusion of insulin secretory granules have sufficient sensitivity but are complicated by endocytosis events and are best for determining the effects of imposed changes in membrane potential (Ämmälä et al., 1993c). Amperometric detection of serotonin released together with insulin from preloaded $\beta$-cells can be used to detect secretion events close to the fibre (Kennedy et al., 1993) but does not provide information about total secretion. Using an extracellular indicator that detects $\mathrm{Zn}^{2+}$ co-secreted with insulin, it was possible to study pulsatile insulin release in parallel with synchronized oscillations of $\left[\mathrm{Ca}^{2+}\right]_{\mathrm{i}}$ in small clusters of $\beta$-cells (Qian et al., 2004). Pulsatile insulin secretion synchronous with oscillations in $\left[\mathrm{Ca}^{2+}\right]_{\mathrm{i}}$ has also been detected in individual human $\beta$-cells with total internal reflection (TIRF) microscopy of fluorescent cargo protein expressed in the secretory granules (Michael et al., 2007). An alternative TIRF-based approach detecting formation of phosphatidylinositol 3,4,5- 
trisphosphate $\left(\mathrm{PIP}_{3}\right)$ in response to autocrine activation of insulin receptors (Idevall-Hagren and Tengholm, 2006) allowed detection of synchronous oscillations of $\left[\mathrm{Ca}^{2+}\right]_{\mathrm{i}}$ and pulsatile insulin release from individual clonal $\beta$-cells with similar frequency as pulsatile secretion in vivo. Figure 1 shows insulin oscillations at different organizational levels. Since major features of pulsatile insulin secretion from single $\beta$-cells in vitro are similar to secretion from the pancreas in vivo, we will evade some of the complexity and concentrate the subsequent discussion on factors determining pulsatile secretion in the individual $\beta$-cell.

\section{Role of metabolism for glucose-induced insulin secretion}

It was early suggested that glucose is recognized as an insulin secretagogue by being metabolized by the $\beta$-cells (Grodsky et al., 1963; Coore and Randle, 1964). This idea, referred to as "the substrate site hypothesis" (Randle et al., 1968), slowly became widely accepted. An early key observation was that glucose-stimulated insulin secretion is prevented by mannoheptulose, a competitive inhibitor of glucose phosphorylation (Coore and Randle, 1964). It was not until 20 years later after the invention of the patch clamp technique that ATP (Ashcroft et al., 1984; Cook and Hales, 1984) or the ATP/ADP ratio (Ashcroft and Rorsman, 1989) could be identified as a primary factor coupling glucose metabolism to insulin secretion. ATP acts by inhibiting ATP-sensitive $\mathrm{K}^{+}\left(\mathrm{K}_{\text {ATP }}\right)$ channels, thus confirming the early and innovative proposal that glucose depolarizes the $\beta$-cells by inhibiting the $\mathrm{K}^{+}$permeability (Sehlin and Täljedal, 1975). It is this depolarization that raises $\left[\mathrm{Ca}^{2+}\right]_{\mathrm{i}}$ and triggers secretion by opening voltage-dependent $\mathrm{Ca}^{2+}$ channels (see below). However, there may be additional mechanisms contributing to depolarization, since glucose can still stimulate some voltagedependent $\mathrm{Ca}^{2+}$ entry in $\beta$-cells lacking functional $\mathrm{K}_{\mathrm{ATP}}$ channels (Szollosi et al., 2007). 
The dose-response relationship for glucose-induced insulin secretion is sigmoidal with a species-dependent stimulatory threshold at 3-7 $\mathrm{mM}$ and a steep increase, reaching maximum at 15-30 mM of the sugar (Henquin et al., 2006; Salehi et al., 2006). Such glucose dependence is consistent with the fact that high $\mathrm{K}_{\mathrm{m}}$ GLUT2 is the dominating glucose transporter in rodent $\beta$-cells (Chen et al., 1990; Johnson et al., 1990). It was therefore unexpected that human $\beta$-cells preferentially express low $\mathrm{K}_{\mathrm{m}}$ GLUT1 (De Vos et al., 1995), whose capacity is close to saturation already at threshold concentrations of glucose. However, consistent with the latter observation, transgenic re-expression of GLUT1 or GLUT2 into $\beta$-cells of GLUT2-null mice were equally efficient in restoring normal glucose sensing (Thorens et al., 2000). The explanation is probably a very high glucose transport capacity that is not rate limiting. Indeed, the uptake is so rapid that reduction of the temperature to $8{ }^{\circ} \mathrm{C}$ was required in the first demonstration of a carrier-mediated saturable uptake of glucose into pancreatic islets (Hellman et al., 1971). The rate-limiting glucosensor that determines the characteristic sigmoidal glucose concentration dependence of insulin secretion is instead the first phosphorylation step in glucose metabolism exerted by the high $\mathrm{K}_{\mathrm{m}}$ glucokinase (Matschinsky, 1990).

Early studies emphasized glycolysis as a likely origin of factors coupling glucose metabolism to insulin secretion (Hellman, 1970). However, the discovery that $\beta$-cell depolarization with increase of $\left[\mathrm{Ca}^{2+}\right]_{\mathrm{i}}$ depends on ATP (Ashcroft et al., 1984; Cook and Hales, 1984) shifts attention towards oxidative metabolism as most ATP is produced by mitochondria. Since secretion is pulsatile it is obvious that oscillations in metabolism and ATP generation may underlie this pattern. Indeed, there is ample evidence supporting the occurrence of metabolic oscillations. Parallel oscillations in oxygen consumption and $\left[\mathrm{Ca}^{2+}\right]_{\mathrm{i}}$ 
were first found in studies of groups of perifused islets (Longo et al., 1991). Oxygen oscillations with similar temporal properties as those of $\left[\mathrm{Ca}^{2+}\right]_{i}$ have later been demonstrated with intra-islet electrodes (Jung et al., 1999a; Jung et al., 1999b; Jung et al., 2000; Ortsäter et al., 2000), and found to correlate with oscillations in glucose consumption (Jung et al., 2000) and insulin release (Ortsäter et al., 2000). Oscillations in NAD $(\mathrm{P}) \mathrm{H}$ have been observed in single rat $\beta$-cells (Pralong et al., 1994) but have been difficult to catch in islets (Panten et al., 1973; Gilon and Henquin, 1992). It was not until recently that NAD(P)H oscillations were convincingly demonstrated in islets (Luciani et al., 2006) where they are coupled to the $\left[\mathrm{Ca}^{2+}\right]_{\mathrm{i}}$ oscillations. Also the mitochondrial membrane potential oscillates in parallel with $\left[\mathrm{Ca}^{2+}\right]_{\mathrm{i}}$ (Krippeit-Drews et al., 2000) and with temporal characteristics similar to that of the NAD(P)H oscillations (Luciani et al., 2006). Direct observations of oscillations in ATP have been made both in individual mouse and human $\beta$-cells (Ainscow and Rutter, 2002), and there is evidence for oscillations in the activity of the $\mathrm{K}_{\mathrm{ATP}}$ channels (Dryselius et al., 1994; Larsson et al., 1996), which are probably the most important ATP targets in stimulussecretion coupling.

There are different ideas how oscillations in metabolism are generated. According to one hypothesis oscillations are an inherent property of metabolism (Tornheim, 1997). Another possibility involves feedback effects of $\mathrm{Ca}^{2+}$ on metabolism (Detimary et al., 1998; Magnus and Keizer, 1998a; Magnus and Keizer, 1998b; Jung et al., 2000; Krippeit-Drews et al., 2000; Kindmark et al., 2001; Ainscow and Rutter, 2002; Luciani et al., 2006; Bertram et al., 2007a). According to the former alternative the metabolic oscillations originate in glycolysis due to allosteric feedback activation of the "oscillatory" isoform of phosphofructokinase (PFK-M) in $\beta$-cells (Tornheim, 1997). However, oscillations in $\left[\mathrm{Ca}^{2+}\right]_{\mathrm{i}}$ remained normal after $95-98 \%$ 
suppression of PFK-M activity in mouse islets (Richard et al., 2007). Moreover, oscillations of $\left[\mathrm{Ca}^{2+}\right]_{\mathrm{i}}$ are not only generated by glucose, but also by mitochondrial substrates like leucine (Grapengiesser et al., 1989b), $\alpha$-ketoisocaproic acid (Martin et al., 1995; Heart and Smith, 2007) and methyl pyruvate (Heart and Smith, 2007) even in the absence of glycolytic flux (Heart and Smith, 2007), although some of these observations are controversial (Lenzen et al., 2000; Dahlgren et al., 2005). Since citrate oscillates in isolated islet mitochondria, it has also been proposed that there is an independent mitochondrial oscillator and that exported citrate may feedback-coordinate mitochondrial and glycolytic oscillations (MacDonald et al., 2003).

As increased metabolism depolarizes the $\beta$-cells and raises $\left[\mathrm{Ca}^{2+}\right]_{\mathrm{i}}$ it seems likely that primary oscillations in metabolism drives those of $\left[\mathrm{Ca}^{2+}\right]_{i}$. However, there are also mechanisms by which $\mathrm{Ca}^{2+}$ may feedback-regulate metabolism. Rise of $\left[\mathrm{Ca}^{2+}\right]_{\mathrm{i}}$ thus increases ATP consumption due to energy-demanding elimination of the cation from the cytoplasm (Detimary et al., 1998). In addition, $\mathrm{Ca}^{2+}$ decreases ATP production by depolarizing the mitochondrial inner membrane by its uptake via the uniporter (Magnus and Keizer, 1997; Magnus and Keizer, 1998b; Krippeit-Drews et al., 2000). The situation is further complicated by the fact that $\mathrm{Ca}^{2+}$ stimulates metabolism by activating mitochondrial dehydrogenases (McCormack et al., 1990; Civelek et al., 1996; Pitter et al., 2002) and that $\mathrm{Ca}^{2+}$ may regulate glycolytic enzymes (Jung et al., 2000). Metabolic oscillations may indeed reflect intrinsic oscillatory mechanisms in glucose metabolism, but the oscillations are modified both by stimulatory and inhibitory feedback effects of $\mathrm{Ca}^{2+}$ (Luciani et al., 2006; Bertram et al., 2007b)

So far the discussion about metabolism has been focussed on the classical $\mathrm{K}_{\mathrm{ATP}}$ channeldependent pathway leading to depolarization, rise of $\left[\mathrm{Ca}^{2+}\right]_{\mathrm{i}}$ and triggering of insulin release. 
However, some of the concentration-dependent stimulatory effect of glucose on insulin secretion remains when $\left[\mathrm{Ca}^{2+}\right]_{\mathrm{i}}$ is elevated under conditions when the $\mathrm{K}_{\mathrm{ATP}}$ channels are either blocked or held open (Henquin, 2000) or after knocking out functional $\mathrm{K}_{\mathrm{ATP}}$ channels (Nenquin et al., 2004; Szollosi et al., 2007). This $\mathrm{K}_{\mathrm{ATP}}$ channel-independent process is mostly considered as an amplification mechanism, which remains functionally silent unless $\left[\mathrm{Ca}^{2+}\right]_{\mathrm{i}}$ is elevated. Yet other studies have provided evidence that the $\mathrm{K}_{\mathrm{ATP}}$ channel-independent pathway may also exhibit triggering properties, since glucose under some conditions stimulates insulin release in a $\mathrm{Ca}^{2+}$-independent manner (Komatsu et al., 1995; Komatsu et al., 1996; Komatsu et al., 2001). The $\mathrm{K}_{\mathrm{ATP}}$ channel-independent pathway has remained elusive and many mechanisms have been proposed (reviewed in (Komatsu et al., 2001)). Changes in ATP concentration is an attractive explanation, since the nucleotide not only closes the $\mathrm{K}_{\text {ATP }}$ channels, but also provides energy for a large number of processes, like insulin granule transport to the plasma membrane (Varadi et al., 2002; Varadi et al., 2003; Varadi et al., 2005) and priming of the granules prior to exocytosis (Eliasson et al., 1997). The ATP-derived product cAMP is another appealing alternative, since it is probably the most important stimulatory messenger after $\mathrm{Ca}^{2+}$ (see below). The observations that pulsatile insulin release is maintained under basal conditions with no elevation of $\left[\mathrm{Ca}^{2+}\right]_{\mathrm{i}}$ (Westerlund et al., 1996) or when $\left[\mathrm{Ca}^{2+}\right]_{\mathrm{i}}$ is elevated to a stable level (Westerlund et al., 1997) indicate that metabolic oscillations do not necessarily require $\mathrm{Ca}^{2+}$ feedback and that such oscillations promote pulsatile secretion via the $\mathrm{K}_{\mathrm{ATP}}$ channel-independent pathway. 


\section{The cytoplasmic $\mathrm{Ca}^{2+}$ concentration}

It has been known for more than 40 years that extracellular $\mathrm{Ca}^{2+}$ is a prerequisite for glucosestimulated insulin secretion (Grodsky and Bennett, 1966; Milner and Hales, 1967) and numerous later studies have emphasized the fundamental role of $\mathrm{Ca}^{2+}$ in the insulin secretory process (Wollheim and Sharp, 1981; Hellman and Gylfe, 1986b; Ashcroft and Rorsman, 1989). $\mathrm{Ca}^{2+}$ stimulates insulin secretion by regulating docking and initiating fusion of secretory granules with the plasma membrane, a process mediated by SNARE proteins (Rorsman and Renström, 2003; MacDonald and Rorsman, 2007). Voltage-dependent $\mathrm{Ca}^{2+}$ entry is actually directed to the sites of exocytosis via the binding of the L-type $\mathrm{Ca}^{2+}$ channels to SNARE proteins (Wiser et al., 1999). Release of $\mathrm{Ca}^{2+}$ from intracellular stores, on the other hand, is essential for the amplification of insulin secretion by promoting the replenishment of the readily releasable pool of secretory granules (Gromada et al., 1999).

In 1988 it was discovered that glucose-stimulated individual $\beta$-cells show pronounced $\left[\mathrm{Ca}^{2+}\right]_{\mathrm{i}}$ oscillations with a periodicity of 2-6 min (Grapengiesser et al., 1988b). These slow $\left[\mathrm{Ca}^{2+}\right]_{\mathrm{i}}$ oscillations are classical membrane oscillations that depend on the presence of extracellular $\mathrm{Ca}^{2+}$ and are inhibited by blockers of voltage-dependent $\mathrm{Ca}^{2+}$ channels ((Grapengiesser et al., 1989a); Table 1). As discussed above the depolarization is due to increased ATP/ADP ratio and closure of $\mathrm{K}_{\mathrm{ATP}}$ channels. The electrophysiological events resulting in slow $\left[\mathrm{Ca}^{2+}\right]_{\mathrm{i}}$ oscillations in individual $\beta$-cells have been difficult to demonstrate. So far there is only one study reporting that each slow $\left[\mathrm{Ca}^{2+}\right]_{\mathrm{i}}$ oscillation is paralleled by an extended burst of electrical activity with action currents ((Dryselius et al., 1999); Figure 2C). The initial rise of $\left[\mathrm{Ca}^{2+}\right]_{\mathrm{i}}$ is preceded by a lowering ((Grapengiesser et al., 1988a); Figure 2A) that essentially reflects ATP-stimulated $\mathrm{Ca}^{2+}$ sequestration in the endoplasmic reticulum (ER; 
(Tengholm et al., 1999)) that becomes masked when depolarization has reached the threshold for voltage-dependent $\mathrm{Ca}^{2+}$ entry (Chow et al., 1995). The lowering is prevented by inhibiting the sarco(endo)plasmic reticulum $\mathrm{Ca}^{2+}$ ATPase (SERCA; (Chow et al., 1995)) and has been attributed to a high affinity SERCA2 mechanism, since it remains after ablation of the low affinity SERCA3 transporter (Arredouani et al., 2002).

Although intracellular sequestration and release of $\mathrm{Ca}^{2+}$ from the ER does not seem to be an absolute requirement for generating slow $\left[\mathrm{Ca}^{2+}\right]_{\mathrm{i}}$ oscillations (Liu et al., 1996), these processes contribute to shaping the oscillations (Fridlyand et al., 2003). SERCA inhibition (Gilon et al., 1999) or selective SERCA3 ablation (Arredouani et al., 2002) consequently accelerates both the rising and declining phases of each oscillation and increases the amplitude, indicating that the ER acts as a low affinity passive $\mathrm{Ca}^{2+}$ buffer to smooth the $\left[\mathrm{Ca}^{2+}\right]_{\mathrm{i}}$ oscillations. There is also gated release of $\mathrm{Ca}^{2+}$ from the ER via inositol $1,4,5-$ trisphosphate receptors $\left(\mathrm{IP}_{3} \mathrm{Rs}\right)$ causing pronounced $\left[\mathrm{Ca}^{2+}\right]_{\mathrm{i}}$ spikes (Table 1). Such release can be triggered after activation of phosphoinositide-specific phospholipase C (PLC) by G-protein coupled hormone receptors (Grapengiesser et al., 1989a). Also elevation of cAMP promotes irregular $\mathrm{Ca}^{2+}$ spiking that is superimposed on top of the slow oscillations or on a stably elevated $\left[\mathrm{Ca}^{2+}\right]_{\mathrm{i}}$ level (Grapengiesser et al., 1991; Liu et al., 1996; Dyachok and Gylfe, 2004), reflecting facilitation of $\mathrm{Ca}^{2+}$-induced $\mathrm{Ca}^{2+}$ release (CICR) via $\mathrm{IP}_{3} \mathrm{Rs}$ (Dyachok and Gylfe, 2004). $\mathrm{Ca}^{2+}$ spiking is sufficiently pronounced to activate a hyperpolarizing $\mathrm{K}^{+}$current that can arrest action potential firing (Ämmälä et al., 1993b; Dryselius et al., 1999) and provide a negative feedback on the slow $\left[\mathrm{Ca}^{2+}\right]_{\mathrm{i}}$ oscillations (Bertram et al., 2007a; Bertram et al., 2007b) independent of the $\mathrm{Ca}^{2+}$ effects on metabolism discussed above (Figure 2D). 
Interestingly, $\mathrm{Ca}^{2+}$ spikes resulting from intracellular $\mathrm{Ca}^{2+}$ mobilization can be synchronized among isolated cells lacking physical contact (Grapengiesser et al., 1999) Figure 2B). These oscillations are sensitive to purinergic P2 receptor antagonists, indicating that $\beta$-cells communicate via release of ATP (Hellman et al., 2004). Since a distinct $\left[\mathrm{Ca}^{2+}\right]_{\mathrm{i}}$ spike results in exocytotic release of ATP co-stored with insulin (Dyachok and Gylfe, 2004; Braun et al., 2007), intercellular diffusion of the nucleotide can result in propagation of $\left[\mathrm{Ca}^{2+}\right]_{\mathrm{i}}$ spikes between cells lacking physical contact (Hellman et al., 2004). The implication of this intercellular communication for oscillatory control of insulin secretion is that the $\left[\mathrm{Ca}^{2+}\right]_{\mathrm{i}}$ spikes can synchronize the slow glucose-induced $\mathrm{Ca}^{2+}$ oscillations by resetting their phase relationship (Grapengiesser et al., 2004). This mechanism may serve as a complement to synchronization by gap junctional coupling within the islet, but is probably more important for the entrainment of different islets to a common rhythm. The synchronizing spiking among islets can be initiated by ATP released from intrapancreatic neurons (Salehi et al., 2005).

Isolated pancreatic islets not only show slow oscillations of $\left[\mathrm{Ca}^{2+}\right]_{\mathrm{i}}$ but often several-fold faster regular oscillations or slow oscillations with superimposed fast ones ((Bergsten et al., 1994; Liu et al., 1998); Table 1). Also the fast oscillations correlate with cyclic membrane depolarization with bursts of electrical activity (Santos et al., 1991). They somehow codepend on the $\mathrm{Ca}^{2+}$ handling by the ER, since fast islet oscillations are immediately transformed into slow ones by SERCA inhibition (Liu et al., 1998). Like the slow $\left[\mathrm{Ca}^{2+}\right]_{\mathrm{i}}$ oscillations, the fast ones generate pulsatile insulin release from individual pancreatic islets (Bergsten, 1995). However, pulsatile insulin release from the pancreas does not show this fast component probably because the fast bursting is not synchronized between islets in the 
pancreas (Valdeolmillos et al., 1996). Therefore, the complex mechanisms underlying the fast islet oscillations will not be further discussed.

\section{PIP 2 and signalling via phospholipase $\mathrm{C}$}

Phosphatidylinositol-4,5-bisphosphate $\left(\mathrm{PIP}_{2}\right)$ constitutes only $\sim 1 \%$ of the phospholipids in the inner leaflet of the plasma membrane (McLaughlin et al., 2002), but nevertheless plays an important role in secretion by regulating vesicle priming and trafficking (Olsen et al., 2003; Gromada et al., 2005; Waselle et al., 2005) and by serving as precursor for second messengers. One of the best known functions of $\mathrm{PIP}_{2}$ is as substrate for PLC generation of $\mathrm{IP}_{3}$ and diacylglycerol (DAG; (Berridge et al., 2000)). Whereas $\mathrm{IP}_{3}$ mobilizes $\mathrm{Ca}^{2+}$ from the ER, DAG plays an important role as activator of protein kinase C (PKC). PLC activity was early detected in rodent islets (Schrey and Montague, 1983; Dunlop and Larkins, 1986), and subsequent analyses have demonstrated islet expression of several PLC $-\beta,-\gamma$, and $-\delta$ isozymes (Kelley et al., 1995; Zawalich et al., 1995; Gasa et al., 1999; Zawalich and Zawalich, 2000; Kim et al., 2001a; Kim et al., 2001b). The importance of PLC activity for insulin secretion is underlined by the fact that the enzyme is activated not only after exposure of islets and $\beta$-cells to various G-protein coupled receptor stimuli, such as acetylcholine/carbachol (Best and Malaisse, 1983; Hellman and Gylfe, 1986a; Best et al., 1987; Biden et al., 1987; Gilon and Henquin, 2001) and ATP (Gylfe and Hellman, 1987; Blachier and Malaisse, 1988), but also after exposure to glucose (Axen et al., 1983; Best and Malaisse, 1983; Laychock, 1983; Montague et al., 1985) and depolarizing agents (Laychock, 1983; Mathias et al., 1985; Best et al., 1987; Biden et al., 1987; Zawalich and Zawalich, 1988). 
$\beta$-cells often respond to PLC-activating receptor agonists with oscillations of $\left[\mathrm{Ca}^{2+}\right]_{\mathrm{i}}$ (Prentki et al., 1988; Gylfe, 1991; Hellman et al., 1992; Theler et al., 1992; Miura et al., 1996) and these oscillations are characterized by a much shorter period than the glucose-induced, slow oscillations described above. Most of the $\left[\mathrm{Ca}^{2+}\right]_{\mathrm{i}}$-elevating effect is due to $\mathrm{IP}_{3}$-mediated $\mathrm{Ca}^{2+}$ mobilization from the ER, but the emptying of the stores also triggers $\mathrm{Ca}^{2+}$ entry through store-operated channels in the plasma membrane (Liu and Gylfe, 1997; Miura et al., 1997; Dyachok and Gylfe, 2001). Although the store-operated influx of $\mathrm{Ca}^{2+}$ only causes a small elevation of $\left[\mathrm{Ca}^{2+}\right]_{\mathrm{i}}$, this pathway may also contribute by its depolarizing effect. In this regard, it is pertinent that $\mathrm{Na}^{+}$can permeate the store-operated channels (Worley et al., 1994a; Worley et al., 1994b). Increased $\mathrm{Na}^{+}$entry actually explains the depolarizing effect of muscarinic stimulation that triggers voltage-dependent $\mathrm{Ca}^{2+}$ entry (Gagerman et al., 1980; Henquin et al., 1988; Saha and Hellman, 1991; Gilon and Henquin, 1993; Gilon and Henquin, 2001), although $\mathrm{Na}^{+}$channels other than store-operated channels probably contribute to this depolarization (Miura et al., 1996; Gilon and Henquin, 2001).

Over the last decade it has become possible to image the kinetics of PLC activity in individual cells using $\mathrm{PIP}_{2}$ - and/or $\mathrm{IP}_{3}$-binding protein domains fused to the green fluorescent protein or its colour variants (Varnai and Balla, 2006). Such reporter proteins shuttle between the plasma membrane and cytoplasm depending on the relative concentrations of $\mathrm{PIP}_{2}$ and $\mathrm{IP}_{3}$ in the two compartments, and this translocation serves as an indirect read-out for PLC activity (Figure 3A). Kinetic analysis of PLC activity in single $\beta$-cells has revealed that receptorinduced PLC activity is under tight dynamic control of $\left[\mathrm{Ca}^{2+}\right]_{i}$ (Thore et al., 2005). In mouse insulinoma cells, carbachol was found to activate PLC in two distinct phases, with a rapid and transient first phase that was amplified several-fold by $\mathrm{Ca}^{2+}$ released from intracellular stores, 
followed by a second phase sustained by store-operated $\mathrm{Ca}^{2+}$ entry ((Thore et al., 2005); Figure 3B). The same study demonstrated that feedback activation of PLC by $\mathrm{Ca}^{2+}$ mobilized from intracellular stores is part of the mechanism by which cAMP generates $\left[\mathrm{Ca}^{2+}\right]_{\mathrm{i}}$ spikes in mouse $\beta$-cells. The importance of such spikes for membrane repolarization and synchronization of $\beta$-cell oscillatory activity is discussed above.

The activation of islet PLC by glucose (Axen et al., 1983; Best and Malaisse, 1983; Laychock, 1983; Montague et al., 1985) and depolarizing agents (Laychock, 1983; Mathias et al., 1985; Best et al., 1987; Biden et al., 1987; Zawalich and Zawalich, 1988) is mainly due to depolarization and $\mathrm{Ca}^{2+}$ influx, although some glucose-stimulated $\mathrm{PIP}_{2}$ hydrolysis was reported to proceed even under conditions when elevation of $\left[\mathrm{Ca}^{2+}\right]_{\mathrm{i}}$ was prevented (Best and Malaisse, 1983; Kelley et al., 1995). Real-time imaging studies in isolated insulinoma cells and intact islets (Thore et al., 2004; Tamarina et al., 2005; Thore et al., 2007) have recently confirmed that glucose stimulates PLC activity secondary to the elevation of $\left[\mathrm{Ca}^{2+}\right]_{\mathrm{i}}$ and that membrane depolarization alone (Gromada et al., 1996; Liu et al., 1996) or increase of $\left[\mathrm{Ca}^{2+}\right]_{\mathrm{i}}$ (Mathias et al., 1985; Best et al., 1987; Biden et al., 1987) are sufficient to activate the enzyme. Depolarization with accompanying elevation of $\left[\mathrm{Ca}^{2+}\right]_{\mathrm{i}}$ is particularly effective in activating PLC, and $\left[\mathrm{Ca}^{2+}\right]_{\mathrm{i}}$ oscillations due to voltage-dependent influx of $\mathrm{Ca}^{2+}$ are therefore associated with periodic activation of PLC ((Thore et al., 2004; Thore et al., 2007); Figure 3C,D). By generating $\mathrm{Ca}^{2+}$-mobilizing $\mathrm{IP}_{3}$, this mechanism provides a link between $\mathrm{Ca}^{2+}$ influx and release from intracellular stores that is distinct from classical CICR (Dyachok et al., 2004). Although $\mathrm{IP}_{3}$ is not essential for generating the slow $\left[\mathrm{Ca}^{2+}\right]_{\mathrm{i}}$ oscillations, $\mathrm{IP}_{3^{-}}$ mediated $\mathrm{Ca}^{2+}$ mobilization is important for their shaping (see above). 
In addition to contributing to the generation and shaping of $\mathrm{Ca}^{2+}$ signals, PLC activation can be anticipated to regulate insulin secretion kinetics via generation of DAG and activation of PKC. Several conventional, novel and atypical PKC isoforms are expressed in islets and insulin-secreting cells (Jones and Persaud, 1998; Warwar et al., 2006). Activation of the PLCPKC signalling pathway has been proposed to account for the second phase of glucoseinduced insulin secretion (Zawalich and Zawalich, 1996). Conversely, insufficient activation of PLC may underlie both the desensitization of insulin release induced by prolonged exposure to high glucose and suppression of secretion by dexamethasone (Yamazaki et al., 2006a; Yamazaki et al., 2006b; Zawalich et al., 2006). Rapid changes in DAG formation have been detected in rat islets following stimulation with glucose or carbachol (Peter-Riesch et al., 1988; Wolf et al., 1989). Although DAG analogues and phorbol esters have been found to stimulate insulin secretion (Virji et al., 1978; Malaisse et al., 1980; Jones et al., 1985) by sensitizing the secretory machinery to $\mathrm{Ca}^{2+}$ (Jones et al., 1985; Tamagawa et al., 1985), it is debated whether PKC is involved in nutrient-induced insulin secretion (Metz, 1988; Jones and Persaud, 1998). The use of PKC inhibitors has resulted in conflicting conclusions (Jones and Persaud, 1998). Recent studies of PKC isoform-selective knock-out mice have indicated important roles for PKC $\delta$ and $-\lambda$ in insulin secretion (Hashimoto et al., 2005; Uchida et al., 2007). Deletion of PKC $\varepsilon$ did not affect normal glucose-induced insulin secretion, but amplified that in islets treated with fatty acids (Schmitz-Peiffer et al., 2007). However, another study showed that expression of a dominant negative mutant of PKC $\varepsilon$ suppressed insulin exocytosis in isolated $\beta$-cells (Mendez et al., 2003). Some of the difficulties to define the role of PKC in insulin secretion may be due to the enzyme being transiently activated during the oscillatory PLC activity. Consistent with this idea, coordinated oscillations of 
$\left[\mathrm{Ca}^{2+}\right]_{\mathrm{i}}$ and membrane translocation of PKC $\alpha,-\beta \mathrm{II}$ and $-\varepsilon$ have been observed in both clonal and primary $\beta$-cells (Pinton et al., 2002; Zhang et al., 2004; Suzuki et al., 2006).

\section{Cyclic AMP}

Next to $\mathrm{Ca}^{2+}$, cAMP is the most critical messenger for insulin secretion. cAMP is formed by adenylyl cyclases in response to $\mathrm{G}_{\mathrm{s}}$-coupled receptor agonists, such as glucagon, the incretin hormones glucagon-like peptide-1 (GLP-1) and gastric inhibitory popypeptide (GIP), as well as the neuropeptides pitutitary adenylate cyclase activating polypeptide (PACAP) and vasoactive intestinal popypeptide (VIP). Also glucose-stimulated islets show a modest elevation of cAMP (Charles et al., 1973; Grill and Cerasi, 1973; Hellman et al., 1974; Sharp, 1979), an effect that has been attributed to the elevation of $\left[\mathrm{Ca}^{2+}\right]_{\mathrm{i}}($ Charles et al., 1975; Valverde et al., 1979). From the observation that purified $\beta$-cells, lacking influence from the glucagon-producing $\alpha$-cells, show reduced cAMP content and impaired secretory capacity, it was suggested that cAMP has a permissive role in glucose-induced insulin release and that the effect of the sugar on cAMP content represents amplification of glucagon-induced cAMP production (Schuit and Pipeleers, 1985). Among several adenylyl cyclases expressed in islet cells and insulin-secreting cell lines (Leech et al., 1999; Guenifi et al., 2000; Delmeire et al., 2003), the $\mathrm{Ca}^{2+}$-sensitive AC8 isoform has been proposed to integrate the cAMP responses to glucose and hormone receptor stimuli (Delmeire et al., 2003).

Early studies demonstrated that cAMP amplifies secretion in response to various initiators by promoting electrical activity and $\mathrm{Ca}^{2+}$ signals (Gylfe and Hellman, 1981; Henquin and Meissner, 1984; Eddlestone et al., 1985; Hellman et al., 1992), as well as by sensitizing the secretory machinery to $\mathrm{Ca}^{2+}$ (Tamagawa et al., 1985; Jones et al., 1986; Hellman et al., 1992). 
The effect of cAMP on $\mathrm{Ca}^{2+}$ signals involves stimulation of both voltage-dependent $\mathrm{Ca}^{2+}$ entry and intracellular mobilization of the ion from the ER (Prentki et al., 1987; Prentki and Matschinsky, 1987; Grapengiesser et al., 1989a; Liu et al., 1996). While the former effect can be explained by PKA phosphorylation of voltage-dependent $\mathrm{Ca}^{2+}$ channels (Ämmälä et al., 1993a; Kanno et al., 1998) and $\mathrm{K}_{\mathrm{ATP}}$ channels (Holz et al., 1993; Gromada et al., 2004), the intracellular mobilization is most likely due to PKA phosphorylation and sensitization of $\mathrm{IP}_{3}$ receptors (Liu et al., 1996; Dyachok and Gylfe, 2004). In addition to these mechanisms, cAMP has been reported to promote depolarization and intracellular $\left[\mathrm{Ca}^{2+}\right]_{\mathrm{i}}$ mobilization via the cAMP-dependent guanine nucleotide exchange factor Epac (Kang et al., 2005; Kang et al., 2006), although another study questioned such effects (Dyachok and Gylfe, 2004).

The principal action of cAMP on exocytosis seems to be exerted at a step distal to the elevation of $\left[\mathrm{Ca}^{2+}\right]_{\mathrm{i}}$ (Ämmälä et al., 1993a; Gillis and Misler, 1993). The effects of cAMP on the exocytosis machinery involves both PKA-dependent and -independent mechanisms, the latter most likely mediated by Epac (Renström et al., 1997; Seino and Shibasaki, 2005). Many exocytosis-related proteins have been identified as substrates for PKA (Seino and Shibasaki, 2005), and the subcellular targeting of PKA to its effectors via A-kinase anchoring proteins has been found critical for the stimulatory effect of cAMP-elevating agents on insulin secretion (Lester et al., 1997; Fraser et al., 1998; Lester et al., 2001). Capacitance recordings have indicated that PKA mediates the slower cAMP-dependent mobilization of insulin granules, while Epac accounts for the rapid cAMP-dependent potentiation of exocytosis in $\beta$-cells (Renström et al., 1997; Eliasson et al., 2003). Epac has also been reported to increase the number of fusion sites (Kwan et al., 2007; Shibasaki et al., 2007) and along with PKA the number of granule-granule fusion events (Kwan et al., 2007). The effects of Epac are 
mediated not only by its guanine nucleotide exchange activity on Rap1 (Shibasaki et al., 2007), but also by interactions with several other proteins, including the $K_{\text {ATP }}$ channel regulatory subunit SUR1 (Ozaki et al., 2000; Eliasson et al., 2003), the voltage-dependent $\mathrm{Ca}^{2+}$ channel (Shibasaki et al., 2004) and the insulin granule proteins Rim2 (Ozaki et al., 2000) and Piccolo (Fujimoto et al., 2002).

Until recently, little was known about the spatiotemporal dynamics of cAMP signals in $\beta$-cells. However, the development of novel fluorescent reporters for cAMP in single cells have led to the demonstration that cAMP signals show complex temporal patterns in clonal insulin-secreting cells (Landa et al., 2005; Dyachok et al., 2006). Using a ratiometric evanescent wave microscopy approach, it was found that glucagon and GLP-1 triggered pronounced oscillations of cAMP beneath the plasma membrane of rat insulinoma cells (Dyachok et al., 2006). The hormone-induced cAMP elevations were synchronized with oscillations of $\left[\mathrm{Ca}^{2+}\right]_{\mathrm{i}}$ (Fig.4). In MIN6-cells expressing a fluorescence resonance energy transfer biosensor, monophasic increases of cAMP was recorded in response to the GLP-1 receptor agonist exendin-4 as well as to glucose and depolarizing agents (Landa et al., 2005). When a high glucose concentration was combined with tetraethylammonium inhibition of $\mathrm{K}^{+}$ channels, there were fast oscillations of both $\mathrm{Ca}^{2+}$ and cAMP. In contrast to the GLP-1induced cAMP oscillations (Dyachok et al., 2006), those evoked by tetraethylammonium were anti-synchronous with the oscillations of $\left[\mathrm{Ca}^{2+}\right]_{i}$. This was interpreted as $\mathrm{Ca}^{2+}$-dependent activation of the PDE1 family of phosphodiesterases (Landa et al., 2005). Islets and insulinsecreting cells express both $\mathrm{Ca}^{2+}$-regulated phosphodiesterases (Pyne and Furman, 2003; Landa et al., 2005) and adenylyl cyclases (Leech et al., 1999; Guenifi et al., 2000; Delmeire et al., 2003), and among the cyclases certain isoforms are stimulated, whereas others are 
suppressed by $\mathrm{Ca}^{2+}$ (Willoughby and Cooper, 2007). It is therefore likely that the phase

relationship between cAMP and $\mathrm{Ca}^{2+}$ signals varies depending on the relative expression levels of different adenylyl cyclases and phosphodiesterases as well as on the type of stimulus (Fridlyand et al., 2007). The coordinated elevations and mutual enhancement of $\mathrm{Ca}^{2+}$ and cAMP signals observed in GLP-1-stimulated cells should be an exquisite trigger for exocytosis and may explain how the incretin hormone selectively enhances the pulsatile component of insulin release in healthy and diabetic subjects (Pørksen et al., 1998; Ritzel et al., 2001).

\section{Feedback effect of insulin on secretion}

In addition to its endocrine effects leading to glucose uptake in muscle and adipose tissue and glycogen storage in liver, insulin has autocrine effects on $\beta$-cells, regulating gene transcription (Leibiger et al., 1998; Xu and Rothenberg, 1998; Wu et al., 1999; da Silva Xavier et al., 2000), proliferation (Withers et al., 1998; Kulkarni et al., 1999a; Okada et al., 2007), glucose metabolism (Borelli et al., 2004; Nunemaker et al., 2004), insulin biosynthesis and secretion (reviewed in (Rutter, 1999) and (Leibiger et al., 2002). $\beta$-cells thus express insulin receptors (Verspohl and Ammon, 1980; Patel et al., 1982) as well as downstream adapter and signalling proteins, like insulin receptor substrate proteins IRS-1, -2, -3, -4, PI3kinase and protein kinase B/Akt (Rothenberg et al., 1995; Velloso et al., 1995; Harbeck et al., 1996; Holst et al., 1998; Withers et al., 1998; Kulkarni et al., 1999b; Muller et al., 2006). Both exogenous insulin and endogenous glucose-induced insulin secretion have been found to activate insulin receptors, phosphorylate IRS-1 and activate PI3-kinase (Rothenberg et al., 1995; Velloso et al., 1995). PI3-kinase catalyzes the formation of 3'-phosphorylated 
phosphoinositide lipids, in particular $\mathrm{PIP}_{3}$, and stimulation of islets and insulinoma cells with insulin or glucose is associated with increased levels of $\mathrm{PIP}_{3}$ (Alter and Wolf, 1995; IdevallHagren and Tengholm, 2006; Yu et al., 2007). The presence of $\mathrm{PIP}_{3}$ in non-stimulated $\beta$-cells (Alter and Wolf, 1995; Yu et al., 2007) has been taken to indicate that even basal insulin secretion exerts an autocrine effect ( $\mathrm{Yu}$ et al., 2007). The generation of $\mathrm{PIP}_{3}$ serves to recruit and activate signalling proteins to the plasma membrane. For example, via its $\mathrm{PIP}_{3}$-binding pleckstrin homology $(\mathrm{PH})$ domain, protein kinase $\mathrm{B} / \mathrm{Akt}$ is recruited to the membrane where it becomes phosphorylated by phosphoinositide-dependent kinase 1. In addition to its important role in regulating $\beta$-cell growth and survival (reviewed in (Dickson and Rhodes, 2004)), recent studies indicate that protein kinase B/Akt also regulates insulin granule exocytosis (Bernal-Mizrachi et al., 2004).

It is debated whether insulin stimulates, inhibits or does not influence insulin secretion (Leibiger et al., 2002). Arguments favouring a positive feedback effect include reduced insulin secretion from insulin receptor deficient mouse islets (Kulkarni et al., 1999a) and insulinoma cells (da Silva Xavier et al., 2004), increased insulin secretion in insulinpretreated and IRS-1-overexpressing cells (Xu et al., 2000) as well as a direct stimulatory effect of insulin or an insulin-mimetic compound on secretion from individual cells (Aspinwall et al., 1999) or islets (Westerlund et al., 2002). Insulin is believed to exert its acute stimulatory effect via $\mathrm{Ca}^{2+}$ mobilized from intracellular stores (Xu et al., 1999; Aspinwall et al., 2000; Xu et al., 2000). The underlying mechanism is not clear, but may involve IRS-1mediated SERCA inhibition (Xu et al., 1999; Xu et al., 2000; Borge and Wolf, 2003) or generation of the $\mathrm{Ca}^{2+}$ mobilizing messenger nicotinic acid adenine dinucleotide phosphate (Johnson and Misler, 2002). 
Negative feedback effects of insulin have been proposed based on observations that insulin or C-peptide secretion was suppressed by exogenous insulin in vivo (Elahi et al., 1982) or from the perfused pancreas (Iversen and Miles, 1971). More recent studies have demonstrated reduced insulin secretion from human islets following insulin receptor activation (Persaud et al., 2002), increased $\mathrm{Ca}^{2+}$ signalling and insulin secretion in insulinoma cells deficient in insulin receptors (Ohsugi et al., 2005), and insulin-induced hyperpolarization of $\beta$-cells (Khan et al., 2001). The latter effect likely involves PI3-kinase dependent formation of $\mathrm{PIP}_{3}$, which activates $\mathrm{K}_{\text {ATP }}$ channels (Shyng and Nichols, 1998; Harvey et al., 2000). Additional support for negative feedback comes from observations that insulin secretion is stimulated by PI3-kinase inhibitors (Hagiwara et al., 1995; Zawalich and Zawalich, 2000) or genetic ablation of the PI3-kinase p85 regulatory subunit (Eto et al., 2002). The issue of insulin feedback effect is not yet settled and the reasons for the discordant results are not well understood. A recent study provides a possible solution to some of the inconsistencies by showing that low $(<100 \mathrm{pM})$ insulin concentrations have a stimulatory effect, whereas high concentrations $(>250 \mathrm{nM})$ have an inhibitory effect on C-peptide secretion from isolated islets (Jimenez-Feltstrom et al., 2004).

Considering the feedback effects of insulin it is obvious that pulsatile insulin release might generate oscillations in the insulin signalling pathway. Studies of the of PI3-kinase activity in MIN6 cells with an evanescent wave microscopy technique for monitoring plasma membrane concentrations of $\mathrm{PIP}_{3}$ recently revealed that glucose and insulin co-activate PI3kinase and that glucose-induced insulin secretion is associated with pronounced oscillations of $\mathrm{PIP}_{3}$, reflecting pulsatile insulin secretion from isolated cells (Idevall-Hagren and Tengholm, 2006); Fig. 5). Although the significance of the $\mathrm{PIP}_{3}$ oscillations remains 
uncertain, their frequency and temporal relationship to $\left[\mathrm{Ca}^{2+}\right]_{\mathrm{i}}$ oscillations are entirely consistent with an insulin feedback loop via PI3-kinase activation and formation of $\mathrm{PIP}_{3}$. In this way insulin may contribute to pulsatile insulin release by repolarizing glucose-stimulated $\beta$-cells (Khan et al., 2001; Idevall-Hagren and Tengholm, 2006).

\section{Conclusions and future perspectives}

It is obvious that pulsatile insulin secretion is controlled by many different factors at multiple organizational levels. Importantly, the individual $\beta$-cell possesses an inherent ability to generate oscillatory signals that underlie pulsatile release of insulin. Recent studies have demonstrated that oscillations of $\left[\mathrm{Ca}^{2+}\right]_{i}$ are coordinated with oscillations in $\beta$-cell metabolism, PLC activity as well as intracellular cAMP and plasma membrane phosphoinositide lipid concentrations. There are complex interdependencies between the different messengers and signalling pathways that contribute to the amplitude and shape of the insulin secretory response to nutrients and neurohormonal factors. Several of these pathways may be important targets for pharmacological treatment of type 2 diabetes. Interestingly, both sulphonylureas and GLP-1 treatment improves in vivo pulsatility (Pørksen, 2002), which may be related to the ability of the drugs to generate oscillations of $\left[\mathrm{Ca}^{2+}\right]_{\mathrm{i}}$ (Grapengiesser et al., 1990) and cAMP (Dyachok et al., 2006). Impairment of insulin secretion from the $\beta$-cells is central in the development of type 2 diabetes, but the perturbation of in vivo insulin pulsatility in diabetes does not necessarily reflect a $\beta$-cell defect, since it might result from impaired synchronization of the secretory activity of $\beta$-cells within or between the many islets in the pancreas. 
The significance of pulsatile insulin secretion is mostly discussed with regards to the action of the hormone on the peripheral target tissues, in particular the liver (Pørksen, 2002). However, pulsatile insulin release may also be important at the level of the individual $\beta$-cell. In view of the rapid and strong autocrine activation of insulin receptors in the $\beta$-cell, its insulin signalling machinery might be expected to be strongly and constitutively activate, if not desensitized, if the cells were exposed to extended periods of high insulin concentrations. In contrast, pulsatile insulin release is associated with periods without or with only low intensity autocrine stimulation, which enables the cells to sense the background concentration of circulating insulin and other growth factors crucial for $\beta$-cell function. Since insulin has been suggested to be an important stimulus for $\beta$-cell proliferation in states of insulin resistance (Okada et al., 2007), loss of pulsatile insulin secretion in prediabetic and diabetic states (Lang et al., 1981; O'Rahilly et al., 1988) may not only be envisioned to contribute to insulin resistance in the extrapancreatic target tissues, but also to impair the compensatory expansion of the $\beta$-cell mass.

Future studies will have to clarify the significance of oscillations in different $\beta$-cell signalling pathways as well as the molecular mechanisms underlying their generation. Given the spatio-temporal complexity of cellular signalling, progress in this area will rely on the continued development of tools and technologies for tracking signalling events in individual cells. A combination of real-time recordings of signalling events with traditional biochemical approaches, molecular perturbation strategies and mathematical modelling is required to improve our understanding of oscillatory control of insulin secretion. 


\section{Acknowledgements}

The authors' work is supported by grants from Åke Wiberg's Foundation, the European Foundation for the Study of Diabetes/MSD, the Family Ernfors Foundation, Harald and Greta Jeanssons Foundations, Novo Nordisk Foundation, the Swedish Diabetes Association and the Swedish Research Council.

\section{References}

Ainscow, E.K., Rutter, G.A., 2002. Glucose-stimulated oscillations in free cytosolic ATP concentration imaged in single islet $\beta$-cells: evidence for a $\mathrm{Ca}^{2+}$-dependent mechanism. Diabetes 51 Suppl 1, S162-S170.

Alter, C.A., Wolf, B.A., 1995. Identification of phosphatidylinositol 3,4,5-trisphosphate in pancreatic islets and insulin-secreting $\beta$-cells. Biochem. Biophys. Res. Commun. 208, $190-$ 197.

Ämmälä, C., Ashcroft, F.M., Rorsman, P., 1993a. Calcium-independent potentiation of insulin release by cyclic AMP in single $\beta$-cells. Nature 363, 356-358.

Ämmälä, C., Bokvist, K., Larsson, O., Berggren, P.O., Rorsman, P., 1993b. Demonstration of a novel apamin-insensitive calcium-activated $\mathrm{K}^{+}$channel in mouse pancreatic $\mathrm{B}$ cells. Pflügers Arch. 422, 443-448.

Ämmälä, C., Eliasson, L., Bokvist, K., Larsson, O., Ashcroft, F.M., Rorsman, P., 1993c. Exocytosis elicited by action potentials and voltage-clamp calcium currents in individual mouse pancreatic B-cells. J. Physiol. (Lond). 472, 665-688.

Arredouani, A., Guiot, Y., Jonas, J.C., Liu, L.H., Nenquin, M., Pertusa, J.A., Rahier, J., Rolland, J.F., Shull, G.E., Stevens, M., Wuytack, F., Henquin, J.C., Gilon, P., 2002. SERCA3 ablation does not impair insulin secretion but suggests distinct roles of different sarcoendoplasmic reticulum $\mathrm{Ca}^{2+}$ pumps for $\mathrm{Ca}^{2+}$ homeostasis in pancreatic $\beta$-cells. Diabetes 51, 3245-3253.

Ashcroft, F.M., Harrison, D.E., Ashcroft, S.J.H., 1984. Glucose induces closure of single potassium channels in isolated rat pancreatic $\beta$-cells. Nature $312,446-448$.

Ashcroft, F.M., Rorsman, P., 1989. Electrophysiology of the pancreatic $\beta$-cell. Prog. Biophys. Mol. Biol. 54, 87-143.

Aspinwall, C.A., Lakey, J.R., Kennedy, R.T., 1999. Insulin-stimulated insulin secretion in single pancreatic beta cells. J. Biol. Chem. 274, 6360-6365.

Aspinwall, C.A., Qian, W.J., Roper, M.G., Kulkarni, R.N., Kahn, C.R., Kennedy, R.T., 2000. Roles of insulin receptor substrate-1, phosphatidylinositol 3-kinase, and release of intracellular $\mathrm{Ca}^{2+}$ stores in insulin-stimulated insulin secretion in $\beta$-cells. J. Biol. Chem. 275, 22331-22338.

Axen, K.V., Schubart, U.K., Blake, A.D., Fleischer, N., 1983. Role of $\mathrm{Ca}^{2+}$ in secretagoguestimulated breakdown of phosphatidylinositol in rat pancreatic islets. J. Clin. Invest. 72, $13-21$. 
Bavamian, S., Klee, P., Britan, A., Populaire, C., Caille, D., Cancela, J., Charollais, A., Meda, P., 2007. Islet-cell-to-cell communication as basis for normal insulin secretion. Diabetes, Obesity and Metabolism 9 Suppl 2, 118-132.

Bergsten, P., Hellman, B., 1993a. Glucose-induced cycles of insulin release can be resolved into distinct periods of secretory activity. Biochem. Biophys. Res. Commun. 192, $1182-$ 1188 .

Bergsten, P., Hellman, B., 1993b. Glucose-induced amplitude regulation of pulsatile insulin secretion from individual pancreatic islets. Diabetes 42, 670-674.

Bergsten, P., Grapengiesser, E., Gylfe, E., Tengholm, A., Hellman, B., 1994. Synchronous oscillations of cytoplasmic $\mathrm{Ca}^{2+}$ and insulin release in glucose-stimulated pancreatic islets. J. Biol. Chem. 269, 8749-8753.

Bergsten, P., 1995. Slow and fast oscillations of cytoplasmic $\mathrm{Ca}^{2+}$ in pancreatic islets correspond to pulsatile insulin release. Am. J. Physiol. 268, E282-E287.

Bernal-Mizrachi, E., Fatrai, S., Johnson, J.D., Ohsugi, M., Otani, K., Han, Z., Polonsky, K.S., Permutt, M.A., 2004. Defective insulin secretion and increased susceptibility to experimental diabetes are induced by reduced Akt activity in pancreatic islet $\beta$ cells. J. Clin. Invest. 114, 928-936.

Berridge, M.J., Lipp, P., Bootman, M.D., 2000. The versatility and universality of calcium signalling. Nat. Rev. Mol. Cell Biol. 1, 11-21.

Bertram, R., Satin, L.S., Pedersen, M.G., Luciani, D.S., Sherman, A., 2007a. Interaction of glycolysis and mitochondrial respiration in metabolic oscillations of pancreatic islets. Biophys. J. 92, 1544-1555.

Bertram, R., Sherman, A., Satin, L.S., 2007b. Metabolic and electrical oscillations: partners in controlling pulsatile insulin secretion. Am. J. Physiol. Endocrinol. Metab. 293, E890-E900.

Best, L., Malaisse, W.J., 1983. Stimulation of phosphoinositide breakdown in rat pancreatic islets by glucose and carbamylcholine. Biochem. Biophys. Res. Commun. 116, 9-16.

Best, L., Tomlinson, S., Hawkins, P.T., Downes, C.P., 1987. Production of inositol trisphosphates and inositol tetrakisphosphate in stimulated pancreatic islets. Biochim. Biophys. Acta 927, 112-116.

Biden, T.J., Peter-Riesch, B., Schlegel, W., Wollheim, C.B., 1987. $\mathrm{Ca}^{2+}$-mediated generation of inositol 1,4,5-triphosphate and inositol 1,3,4,5-tetrakisphosphate in pancreatic islets. Studies with $\mathrm{K}^{+}$, glucose, and carbamylcholine. J. Biol. Chem. 262, 3567-3571.

Blachier, F., Malaisse, W.J., 1988. Effect of exogenous ATP upon inositol phosphate production, cationic fluxes and insulin release in pancreatic islet cells. Biochim. Biophys. Acta 970, 222-229.

Borelli, M.I., Francini, F., Gagliardino, J.J., 2004. Autocrine regulation of glucose metabolism in pancreatic islets. Am. J. Physiol. Endocrinol. Metab. 286, E111-E115.

Borge, P.D., Jr., Wolf, B.A., 2003. Insulin receptor substrate 1 regulation of sarcoendoplasmic reticulum calcium ATPase 3 in insulin-secreting $\beta$-cells. J. Biol. Chem. 278, 11359-11368.

Bratusch-Marrain, P.R., Komjati, M., Waldhäusl, W.K., 1986. Efficacy of pulsatile versus continuous insulin administration on hepatic glucose production and glucose utilization in type I diabetic humans. Diabetes 35, 922-926.

Braun, M., Wendt, A., Karanauskaite, J., Galvanovskis, J., Clark, A., MacDonald, P.E., Rorsman, P., 2007. Corelease and differential exit via the fusion pore of GABA, serotonin, and ATP from LDCV in rat pancreatic $\beta$ cells. J. Gen. Physiol. 129, 221-231. 
Charles, M.A., Fanska, R., Schmid, F.G., Forsham, P.H., Grodsky, G.M., 1973. Adenosine 3',5'-monophosphate in pancreatic islets: glucose-induced insulin release. Science 179, $569-571$.

Charles, M.A., Lawecki, J., Pictet, R., Grodsky, G.M., 1975. Insulin secretion. Interrelationships of glucose, cyclic adenosine 3:5-monophosphate, and calcium. J. Biol. Chem. 250, 6134-6140.

Chen, L., Alam, T., Johnson, J.H., Hughes, S., Newgard, C.B., Unger, R.H., 1990. Regulation of $\beta$-cell glucose transporter gene expression. Proc. Natl. Acad. Sci. U. S. A. 87, 40884092.

Chow, R.H., Lund, P.E., Löser, S., Panten, U., Gylfe, E., 1995. Coincidence of early glucoseinduced depolarization with lowering of cytoplasmic $\mathrm{Ca}^{2+}$ in mouse pancreatic $\beta$-cells. $\mathrm{J}$. Physiol. (Lond). 485, 607-617.

Civelek, V.N., Deeney, J.T., Shalosky, N.J., Thornheim, K., Hansford, R.G., Prentki, M., Corkey, B.E., 1996. Regulation of pancreatic $\beta$-cell mitochondrial metabolism: influence of $\mathrm{Ca}^{2+}$, substrate and ADP. Biochem. J. 318, 615-621.

Cook, D.L., Hales, C.N., 1984. Intracellular ATP directly blocks $\mathrm{K}^{+}$channels in pancreatic Bcells. Nature 311, 271-273.

Coore, H.G., Randle, P.J., 1964. Regulation of insulin secretion studied with pieces of rabbit pancreas incubated in vitro. Biochem. J. 93, 66-78.

da Silva Xavier, G., Varadi, A., Ainscow, E.K., Rutter, G.A., 2000. Regulation of gene expression by glucose in pancreatic $\beta$-cells (MIN6) via insulin secretion and activation of phosphatidylinositol 3'-kinase. J. Biol. Chem. 275, 36269-36277.

da Silva Xavier, G., Qian, Q., Cullen, P.J., Rutter, G.A., 2004. Distinct roles for insulin and insulin-like growth factor-1 receptors in pancreatic $\beta$-cell glucose sensing revealed by RNA silencing. Biochem. J. 377, 149-158.

Dahlgren, G.M., Kauri, L.M., Kennedy, R.T., 2005. Substrate effects on oscillations in metabolism, calcium and secretion in single mouse islets of Langerhans. Biochim. Biophys. Acta 1724, 23-36.

De Vos, A., Heimberg, H., Quartier, E., Huypens, P., Bouwens, L., Pipeleers, D., Schuit, F., 1995. Human and rat beta cells differ in glucose transporter but not in glucokinase gene expression. J. Clin. Invest. 96, 2489-2495.

Delmeire, D., Flamez, D., Hinke, S.A., Cali, J.J., Pipeleers, D., Schuit, F., 2003. Type VIII adenylyl cyclase in rat beta cells: coincidence signal detector/generator for glucose and GLP-1. Diabetologia 46, 1383-1393.

Detimary, P., Gilon, P., Henquin, J.C., 1998. Interplay between cytoplasmic $\mathrm{Ca}^{2+}$ and the ATP/ADP ratio: a feedback control mechanism in mouse pancreatic islets. Biochem. $\mathrm{J}$. 333, 269-274.

Dickson, L.M., Rhodes, C.J., 2004. Pancreatic $\beta$-cell growth and survival in the onset of type 2 diabetes: a role for protein kinase B in the Akt? Am. J. Physiol. Endocrinol. Metab. 287, E192-E198.

Dryselius, S., Lund, P.E., Gylfe, E., Hellman, B., 1994. Variations in ATP-sensitive K ${ }^{+}$ channel activity provide evidence for inherent metabolic oscillations in pancreatic $\beta$-cells. Biochem. Biophys. Res. Commun. 205, 880-885.

Dryselius, S., Grapengiesser, E., Hellman, B., Gylfe, E., 1999. Voltage-dependent entry and generation of slow $\mathrm{Ca}^{2+}$ oscillations in glucose-stimulated pancreatic $\beta$-cells. Am. J. Physiol. 276, E512-E518. 
Dunlop, M.E., Larkins, R.G., 1986. Muscarinic-agonist and guanine nucleotide activation of polyphosphoinositide phosphodiesterase in isolated islet-cell membranes. Biochem. J. 240, $731-737$.

Dyachok, O., Gylfe, E., 2001. Store-operated influx of $\mathrm{Ca}^{2+}$ in the pancreatic $\beta$-cells exhibits graded dependence on the filling of the endoplasmic reticulum. J. Cell Sci. 114, 21792186.

Dyachok, O., Gylfe, E., 2004. $\mathrm{Ca}^{2+}$-induced $\mathrm{Ca}^{2+}$ release via inositol 1,4,5-trisphosphate receptors is amplified by protein kinase A and triggers exocytosis in pancreatic $\beta$-cells. J. Biol. Chem. 279, 45455-45461.

Dyachok, O., Tufveson, G., Gylfe, E., 2004. $\mathrm{Ca}^{2+}$-induced $\mathrm{Ca}^{2+}$ release by activation of inositol 1,4,5-trisphosphate receptors in primary pancreatic $\beta$-cells. Cell Calcium 36, 1-9.

Dyachok, O., Isakov, Y., Sågetorp, J., Tengholm, A., 2006. Oscillations of cyclic AMP in hormone-stimulated insulin-secreting $\beta$-cells. Nature 439, 349-352.

Eddlestone, G.T., Oldham, S.B., Lipson, L.G., Premdas, F.H., Beigelman, P.M., 1985. Electrical activity, cAMP concentration, and insulin release in mouse islets of Langerhans. American Journal of Physiolgy 248, C145-C153.

Elahi, D., Nagulesparan, M., Hershcopf, R.J., Muller, D.C., Tobin, J.D., Blix, P.M., Rubenstein, A.H., Unger, R.H., Andres, R., 1982. Feedback inhibition of insulin secretion by insulin: relation to the hyperinsulinemia of obesity. N. Engl. J. Med. 306, 1196-1202.

Eliasson, L., Renström, E., Ding, W.G., Proks, P., Rorsman, P., 1997. Rapid ATP-dependent priming of secretory granules precedes $\mathrm{Ca}^{2+}$-induced exocytosis in mouse pancreatic Bcells. J. Physiol. (Lond). 503 ( Pt 2), 399-412.

Eliasson, L., Ma, X., Renström, E., Barg, S., Berggren, P.O., Galvanovskis, J., Gromada, J., Jing, X., Lundquist, I., Salehi, A., Sewing, S., Rorsman, P., 2003. SUR1 regulates PKAindependent cAMP-induced granule priming in mouse pancreatic B-cells. J. Gen. Physiol. 121, 181-197.

Eto, K., Yamashita, T., Tsubamoto, Y., Terauchi, Y., Hirose, K., Kubota, N., Yamashita, S., Taka, J., Satoh, S., Sekihara, H., Tobe, K., Iino, M., Noda, M., Kimura, S., Kadowaki, T., 2002. Phosphatidylinositol 3-kinase suppresses glucose-stimulated insulin secretion by affecting post-cytosolic $\left[\mathrm{Ca}^{2+}\right]$ elevation signals. Diabetes 51, 87-97.

Fraser, I.D., Tavalin, S.J., Lester, L.B., Langeberg, L.K., Westphal, A.M., Dean, R.A., Marrion, N.V., Scott, J.D., 1998. A novel lipid-anchored A-kinase anchoring protein facilitates cAMP-responsive membrane events. EMBO J. 17, 2261-2272.

Fridlyand, L.E., Tamarina, N., Philipson, L.H., 2003. Modeling of $\mathrm{Ca}^{2+}$ flux in pancreatic $\beta$ cells: role of the plasma membrane and intracellular stores. Am. J. Physiol. Endocrinol. Metab. 285, E138-E154.

Fridlyand, L.E., Harbeck, M.C., Roe, M.W., Philipson, L.H., 2007. Regulation of cAMP dynamics by $\mathrm{Ca}^{2+}$ and $\mathrm{G}$ protein-coupled receptors in the pancreatic $\beta$-cell: a computational approach. Am. J. Physiol. Cell Physiol. 293, C1924-C1933.

Fujimoto, K., Shibasaki, T., Yokoi, N., Kashima, Y., Matsumoto, M., Sasaki, T., Tajima, N., Iwanaga, T., Seino, S., 2002. Piccolo, a $\mathrm{Ca}^{2+}$ sensor in pancreatic $\beta$-cells. Involvement of cAMP-GEFII.Rim2.Piccolo complex in cAMP-dependent exocytosis. J. Biol. Chem. 277, 50497-50502.

Gagerman, E., Sehlin, J., Täljedal, I.B., 1980. Effects of acetylcholine on ion fluxes and chlorotetracycline fluorescence in pancreatic islets. J. Physiol. (Lond). 300, 505-513. 
Gasa, R., Trinh, K.Y., Yu, K., Wilkie, T.M., Newgard, C.B., 1999. Overexpression of $\mathrm{G}_{11}$. and isoforms of phospholipase $\mathrm{C}$ in islet $\beta$-cells reveals a lack of correlation between inositol phosphate accumulation and insulin secretion. Diabetes 48, 1035-1044.

Gillis, K.D., Misler, S., 1993. Enhancers of cytosolic cAMP augment depolarization-induced exocytosis from pancreatic B-cells: evidence for effects distal to $\mathrm{Ca}^{2+}$ entry. Pflügers Arch. 424, 195-197.

Gilon, P., Henquin, J.C., 1992. Influence of membrane potential changes on cytoplasmic $\mathrm{Ca}^{2+}$ concentration in an electrically excitable cell, the insulin-secreting pancreatic B-cell. J. Biol. Chem. 267, 20713-20720.

Gilon, P., Henquin, J.C., 1993. Activation of muscarinic receptors increases the concentration of free $\mathrm{Na}^{+}$in mouse pancreatic B-cells. FEBS Lett. 315, 353-356.

Gilon, P., Shepherd, R.M., Henquin, J.C., 1993. Oscillations of secretion driven by oscillations of cytoplasmic $\mathrm{Ca}^{2+}$ as evidenced in single pancreatic islets. J. Biol. Chem. 268, 22265-22268.

Gilon, P., Henquin, J.C., 1995. Distinct effects of glucose on the synchronous oscillations of insulin release and cytoplasmic $\mathrm{Ca}^{2+}$ concentration measured simultaneously in single mouse islets. Endocrinology 136, 5725-5730.

Gilon, P., Arredouani, A., Gailly, P., Gromada, J., Henquin, J.C., 1999. Uptake and release of $\mathrm{Ca}^{2+}$ by the endoplasmic reticulum contribute to the oscillations of the cytosolic $\mathrm{Ca}^{2+}$ concentration triggered by $\mathrm{Ca}^{2+}$ influx in the electrically excitable pancreatic B-cell. J. Biol. Chem. 274, 20197-20205.

Gilon, P., Henquin, J.C., 2001. Mechanisms and physiological significance of the cholinergic control of pancreatic $\beta$-cell function. Endocr. Rev. 22, 565-604.

Goodner, C.J., Sweet, I.R., Harrison, H.C., 1988. Rapid reduction and return of surface insulin receptors after exposure to brief pulses of insulin in perifused rat hepatocytes. Diabetes 37, 1316-1323.

Grapengiesser, E., Gylfe, E., Hellman, B., 1988a. Dual effect of glucose on cytoplasmic $\mathrm{Ca}^{2+}$ in single pancreatic $\beta$-cells. Biochem. Biophys. Res. Commun. 150, 419-425.

Grapengiesser, E., Gylfe, E., Hellman, B., 1988b. Glucose-induced oscillations of cytoplasmic $\mathrm{Ca}^{2+}$ in the pancreatic $\beta$-cell. Biochem. Biophys. Res. Commun. 151, 12991304.

Grapengiesser, E., Gylfe, E., Hellman, B., 1989a. Three types of cytoplasmic $\mathrm{Ca}^{2+}$ oscillations in stimulated pancreatic $\beta$-cells. Arch. Biochem. Biophys. 268, 404-407.

Grapengiesser, E., Gylfe, E., Hellman, B., 1989b. $\mathrm{Ca}^{2+}$ oscillations in pancreatic $\beta$-cells exposed to leucine and arginine. Acta Physiol. Scand. 136, 113-119.

Grapengiesser, E., Gylfe, E., Hellman, B., 1990. Sulfonylurea mimics the effect of glucose in inducing large amplitude oscillations of cytoplasmic $\mathrm{Ca}^{2+}$ in pancreatic $\beta$-cells. Mol. Pharmacol. 37, 461-467.

Grapengiesser, E., Gylfe, E., Hellman, B., 1991. Cyclic AMP as a determinant for glucose induction of fast $\mathrm{Ca}^{2+}$ oscillations in isolated pancreatic $\beta$-cells. J. Biol. Chem. 266, $12207-$ 12210.

Grapengiesser, E., Gylfe, E., Hellman, B., 1999. Synchronization of glucose-induced $\mathrm{Ca}^{2+}$ transients in pancreatic $\beta$-cells by a diffusible factor. Biochem. Biophys. Res. Commun. 254, 436-439. 
Grapengiesser, E., Gylfe, E., Dansk, H., Hellman, B., 2001. Nitric oxide induces synchronous $\mathrm{Ca}^{2+}$ transients in pancreatic $\beta$-cells lacking contact. Pancreas 23, 387-392.

Grapengiesser, E., Dansk, H., Hellman, B., 2004. Pulses of external ATP aid to the synchronization of pancreatic $\beta$-cells by generating premature $\mathrm{Ca}^{2+}$ oscillations. Biochem. Pharmacol. 68, 667-674.

Grapengiesser, E., Dansk, H., Hellman, B., 2005. External ATP triggers $\mathrm{Ca}^{2+}$ signals suited for synchronization of pancreatic $\beta$-cells. J. Endocrinol. 185, 69-79.

Grill, V., Cerasi, E., 1973. Activation by glucose of adenyl cyclase in pancreatic islets of the rat. FEBS Lett. 33, 311-314.

Grodsky, G.M., Batts, A.A., Bennett, L.L., Vcella, C., McWilliams, N.B., Smith, D.F., 1963. Effects of carbohydrates on secretion of insulin from isolated rat pancreas. Am. J. Physiol. 205, 638-644.

Grodsky, G.M., Bennett, L.L., 1966. Cation requirements for insulin secretion in the isolated perfused pancreas. Diabetes 15, 910-912.

Gromada, J., Frøkjær-Jensen, J., Dissing, S., 1996. Glucose stimulates voltage- and calciumdependent inositol trisphosphate production and intracellular calcium mobilization in insulin-secreting $\beta$ TC3 cells. Biochem. J. 314, 339-345.

Gromada, J., Høy, M., Renström, E., Bokvist, K., Eliasson, L., Göpel, S., Rorsman, P., 1999. $\mathrm{CaM}$ kinase II-dependent mobilization of secretory granules underlies acetylcholineinduced stimulation of exocytosis in mouse pancreatic B-cells. J. Physiol. (Lond). 518, 745-759.

Gromada, J., Brock, B., Schmitz, O., Rorsman, P., 2004. Glucagon-like peptide-1: regulation of insulin secretion and therapeutic potential. Basic Clin. Pharmacol. Toxicol. 95, 252-262.

Gromada, J., Bark, C., Smidt, K., Efanov, A.M., Janson, J., Mandic, S.A., Webb, D.L., Zhang, W., Meister, B., Jeromin, A., Berggren, P.O., 2005. Neuronal calcium sensor-1 potentiates glucose-dependent exocytosis in pancreatic $\beta$ cells through activation of phosphatidylinositol 4-kinase $\beta$. Proc. Natl. Acad. Sci. U. S. A. 102, 10303-8.

Guenifi, A., Portela-Gomes, G.M., Grimelius, L., Efendic, S., Abdel-Halim, S.M., 2000. Adenylyl cyclase isoform expression in non-diabetic and diabetic Goto-Kakizaki (GK) rat pancreas. Evidence for distinct overexpression of type-8 adenylyl cyclase in diabetic GK rat islets. Histochem. Cell Biol. 113, 81-89.

Gylfe, E., Hellman, B., 1981. Calcium and pancreatic $\beta$-cell function. Modification of ${ }^{45} \mathrm{Ca}$ fluxes by methylxanthines and dibutyryl cyclic-AMP. Biochem. Med. 26, 365-376.

Gylfe, E., Hellman, B., 1987. External ATP mimics carbachol in initiating calcium mobilization from pancreatic $\beta$-cells conditioned by previous exposure to glucose. Br. J. Pharmacol. 92, 281-289.

Gylfe, E., 1991. Carbachol induces sustained glucose-dependent oscillations of cytoplasmic $\mathrm{Ca}^{2+}$ in hyperpolarized pancreatic $\beta$-cells. Pflügers Arch. 419, 639-643.

Gylfe, E., Grapengiesser, E., Hellman, B., 1991. Propagation of cytoplasmic $\mathrm{Ca}^{2+}$ oscillations in clusters of pancreatic $\beta$-cells exposed to glucose. Cell Calcium 12, 229-240.

Gylfe, E., Ahmed, M., Bergsten, P., Dansk, H., Dyachok, O., Eberhardson, M., Grapengiesser, E., Hellman, B., Lin, J., Sundsten, T., Tengholm, A., Vieira, E., Westerlund, J., 2000. Signalling underlying pulsatile insulin secretion. Ups. J. Med. Sci. $105,35-51$. 
Hagiwara, S., Sakurai, T., Tashiro, F., Hashimoto, Y., Matsuda, Y., Nonomura, Y., Miyazaki, J., 1995. An inhibitory role for phosphatidylinositol 3-kinase in insulin secretion from pancreatic B cell line MIN6. Biochem. Biophys. Res. Commun. 214, 51-59.

Harbeck, M.C., Louie, D.C., Howland, J., Wolf, B.A., Rothenberg, P.L., 1996. Expression of insulin receptor mRNA and insulin receptor substrate 1 in pancreatic islet $\beta$-cells. Diabetes 45, 711-717.

Harvey, J., Hardy, S.C., Irving, A.J., Ashford, M.L., 2000. Leptin activation of ATP-sensitive $\mathrm{K}+\left(\mathrm{K}_{\mathrm{ATP}}\right)$ channels in rat CRI-G1 insulinoma cells involves disruption of the actin cytoskeleton. J. Physiol. (Lond). 527 Pt 1, 95-107.

Hashimoto, N., Kido, Y., Uchida, T., Matsuda, T., Suzuki, K., Inoue, H., Matsumoto, M., Ogawa, W., Maeda, S., Fujihara, H., Ueta, Y., Uchiyama, Y., Akimoto, K., Ohno, S., Noda, T., Kasuga, M., 2005. PKC $\lambda$ regulates glucose-induced insulin secretion through modulation of gene expression in pancreatic $\beta$ cells. J. Clin. Invest. 115, 138-145.

Heart, E., Smith, P.J., 2007. Rhythm of the $\beta$-cell oscillator is not governed by a single regulator: multiple systems contribute to oscillatory behavior. Am. J. Physiol. Endocrinol. Metab. 292, E1295-E1300.

Hellman, B., 1970. Methodological approaches to studies on the pancreatic islets. Diabetologia 6, 110-120.

Hellman, B., Sehlin, J., Taljedal, I.B., 1971. Evidence for mediated transport of glucose in mammalian pancreatic $\beta$-cells. Biochim. Biophys. Acta 241, 147-154.

Hellman, B., Idahl, L.Å., Lernmark, Å., Täljedal, I.B., 1974. The pancreatic $\beta$-cell recognition of insulin secretagogues: Does cyclic AMP mediate the effect of glucose? Proc. Natl. Acad. Sci. U. S. A. 71, 3405-3409.

Hellman, B., Gylfe, E., 1986a. Mobilization of different intracellular calcium pools after activation of muscarinic receptors in pancreatic beta-cells. Pharmacology 32, 257-267.

Hellman, B., Gylfe, E., 1986b. Calcium and the control of insulin secretion. In: Cheung, W.Y. (ed.), Calcium and cell function vol. VI. Academic Press, Orlando, pp. 253-326.

Hellman, B., Gylfe, E., Grapengiesser, E., Lund, P.E., Marcström, A., 1992. Cytoplasmic calcium and insulin secretion. In: Flatt, P.R. (ed.), Nutrient regulation of insulin secretion. Portland Press, Colchester, pp. 213-246.

Hellman, B., Gylfe, E., Bergsten, P., Grapengiesser, E., Lund, P.E., Berts, A., Tengholm, A., Pipeleers, D.G., Ling, Z., 1994. Glucose induces oscillatory $\mathrm{Ca}^{2+}$ signalling and insulin release in human pancreatic beta cells. Diabetologia 37 (suppl. 2), S11-S20.

Hellman, B., Dansk, H., Grapengiesser, E., 2004. Pancreatic $\beta$-cells communicate via intermittent release of ATP. Am. J. Physiol. Endocrinol. Metab. 286, E759-E765.

Henquin, J.C., Meissner, H.P., 1984. The ionic, electrical, and secretory effects of endogenous cyclic adenosine monophosphate in mouse pancreatic B cells: studies with forskolin. Endocrinology 115, 1125-1134.

Henquin, J.C., Garcia, M.C., Bozem, M., Hermans, M.P., Nenquin, M., 1988. Muscarinic control of pancreatic B cell function involves sodium-dependent depolarization and calcium influx. Endocrinology 122, 2134-2142.

Henquin, J.C., 2000. Triggering and amplifying pathways of regulation of insulin secretion by glucose. Diabetes 49, 1751-1760.

Henquin, J.C., Dufrane, D., Nenquin, M., 2006. Nutrient control of insulin secretion in isolated normal human islets. Diabetes 55, 3470-3477. 
Holst, L.S., Mulder, H., Manganiello, V., Sundler, F., Ahren, B., Holm, C., Degerman, E., 1998. Protein kinase $B$ is expressed in pancreatic $\beta$ cells and activated upon stimulation with insulin-like growth factor I. Biochem. Biophys. Res. Commun. 250, 181-186.

Holz, G.G.t., Kühtreiber, W.M., Habener, J.F., 1993. Pancreatic beta-cells are rendered glucose-competent by the insulinotropic hormone glucagon-like peptide-1(7-37). Nature 361, 362-365.

Idevall-Hagren, O., Tengholm, A., 2006. Glucose and insulin synergistically activate phosphatidylinositol 3-kinase to trigger oscillations of phosphatidylinositol 3,4,5trisphosphate in $\beta$-cells. J. Biol. Chem. 281, 39121-39127.

Iversen, J., Miles, D.W., 1971. Evidence for a feedback inhibition of insulin on insulin secretion in the isolated, perfused canine pancreas. Diabetes 20, 1-9.

Jimenez-Feltstrom, J., Lundquist, I., Obermuller, S., Salehi, A., 2004. Insulin feedback actions: complex effects involving isoforms of islet nitric oxide synthase. Regul. Pept. 122, 109-118.

Johnson, J.D., Misler, S., 2002. Nicotinic acid-adenine dinucleotide phosphate-sensitive calcium stores initiate insulin signaling in human beta cells. Proc. Natl. Acad. Sci. U. S. A. 99, 14566-14571.

Johnson, J.H., Ogawa, A., Chen, L., Orci, L., Newgard, C.B., Alam, T., Unger, R.H., 1990. Underexpression of $\beta$ cell high $\mathrm{K}_{\mathrm{m}}$ glucose transporters in noninsulin-dependent diabetes. Science 250, 546-549.

Jones, P.M., Stutchfield, J., Howell, S.L., 1985. Effects of $\mathrm{Ca}^{2+}$ and a phorbol ester on insulin secretion from islets of Langerhans permeabilised by high-voltage discharge. FEBS Lett. 191, 102-106.

Jones, P.M., Fyles, J.M., Howell, S.L., 1986. Regulation of insulin secretion by cAMP in rat islets of Langerhans permeabilised by high-voltage discharge. FEBS Lett. 205, 205-209.

Jones, P.M., Persaud, S.J., 1998. Protein kinases, protein phosphorylation, and the regulation of insulin secretion from pancreatic $\beta$-cells. Endocr. Rev. 19, 429-461.

Jung, S.K., Aspinwall, C.A., Kennedy, R.T., 1999a. Detection of multiple patterns of oscillatory oxygen consumption in single mouse islets of Langerhans. Biochem. Biophys. Res. Commun. 259, 331-335.

Jung, S.K., Gorski, W., Aspinwall, C.A., Kauri, L.M., Kennedy, R.T., 1999b. Oxygen microsensor and its application to single cells and mouse pancreatic islets. Anal. Chem. 71, 3642-3649.

Jung, S.K., Kauri, L.M., Qian, W.J., Kennedy, R.T., 2000. Correlated oscillations in glucose consumption, oxygen consumption, and intracellular free $\mathrm{Ca}^{2+}$ in single islets of Langerhans. J. Biol. Chem. 275, 6642-6650.

Kang, G., Chepurny, O.G., Rindler, M.J., Collis, L., Chepurny, Z., Li, W.H., Harbeck, M., Roe, M.W., Holz, G.G., 2005. A cAMP and $\mathrm{Ca}^{2+}$ coincidence detector in support of $\mathrm{Ca}^{2+}-$ induced $\mathrm{Ca}^{2+}$ release (CICR) in pancreatic $\beta$-cells. J. Physiol. (Lond). 566, 173-188.

Kang, G., Chepurny, O.G., Malester, B., Rindler, M.J., Rehmann, H., Bos, J.L., Schwede, F., Coetzee, W.A., Holz, G.G., 2006. cAMP sensor Epac as a determinant of ATP-sensitive potassium channel activity in human pancreatic $\beta$ cells and rat INS-1 cells. J. Physiol. (Lond). 573, 595-609.

Kanno, T., Suga, S., Wu, J., Kimura, M., Wakui, M., 1998. Intracellular cAMP potentiates voltage-dependent activation of L-type $\mathrm{Ca}^{2+}$ channels in rat islet $\beta$-cells. Pflügers Arch. $435,578-580$. 
Kelley, G.G., Zawalich, K.C., Zawalich, W.S., 1995. Synergistic interaction of glucose and neurohumoral agonists to stimulate islet phosphoinositide hydrolysis. Am. J. Physiol. 269, E575-E582.

Kennedy, R.T., Huang, L., Atkinson, M.A., Dush, P., 1993. Amperometric monitoring of chemical secretions from individual pancreatic $\beta$-cells. Anal. Chem. 65, 1882-1887.

Khan, F.A., Goforth, P.B., Zhang, M., Satin, L.S., 2001. Insulin activates ATP-sensitive $\mathrm{K}^{+}$ channels in pancreatic $\beta$-cells through a phosphatidylinositol 3-kinase-dependent pathway. Diabetes 50, 2192-2198.

Kim, M.J., Lee, K.H., Min, D.S., Yoon, S.H., Hahn, S.J., Kim, M.S., Jo, Y.H., 2001a. Distributional patterns of phospholipase $\mathrm{C}$ isozymes in rat pancreas. Pancreas 22, 47-52.

Kim, S.S., Jun, K., Jeong, M., Ryu, S.H., Suh, P.G., Shin, H.S., 2001b. Immunohistochemical localization of eight phospholipase $\mathrm{C}$ isozymes in pancreatic islets of the mouse. Exp. Mol. Med. 33, 164-168.

Kindmark, H., Köhler, M., Brown, G., Bränström, R., Larsson, O., Berggren, P.O., 2001. Glucose-induced oscillations in cytoplasmic free $\mathrm{Ca}^{2+}$ concentration precede oscillations in mitochondrial membrane potential in the pancreatic $\beta$-cell. J. Biol. Chem. 276, 3453034536.

Komatsu, M., Schermerhorn, T., Aizawa, T., Sharp, G.W., 1995. Glucose stimulation of insulin release in the absence of extracellular $\mathrm{Ca}^{2+}$ and in the absence of any increase in intracellular $\mathrm{Ca}^{2+}$ in rat pancreatic islets. Proc. Natl. Acad. Sci. U. S. A. 92, 10728-10732.

Komatsu, M., Schermerhorn, T., Straub, S.G., Sharp, G.W., 1996. Pituitary adenylate cyclaseactivating peptide, carbachol, and glucose stimulate insulin release in the absence of an increase in intracellular $\mathrm{Ca}^{2+}$. Mol. Pharmacol. 50, 1047-1054.

Komatsu, M., Sato, Y., Aizawa, T., Hashizume, K., 2001. KATP channel-independent glucose action: an elusive pathway in stimulus-secretion coupling of pancreatic $\beta$-cell. Endocr. J. 48, 275-288.

Krippeit-Drews, P., Düfer, M., Drews, G., 2000. Parallel oscillations of intracellular calcium activity and mitochondrial membrane potential in mouse pancreatic B-cells. Biochem. Biophys. Res. Commun. 267, 179-183.

Kulkarni, R.N., Bruning, J.C., Winnay, J.N., Postic, C., Magnuson, M.A., Kahn, C.R., 1999a. Tissue-specific knockout of the insulin receptor in pancreatic $\beta$ cells creates an insulin secretory defect similar to that in type 2 diabetes. Cell 96, 329-339.

Kulkarni, R.N., Winnay, J.N., Daniels, M., Bruning, J.C., Flier, S.N., Hanahan, D., Kahn, C.R., 1999b. Altered function of insulin receptor substrate-1-deficient mouse islets and cultured $\beta$-cell lines. J. Clin. Invest. 104, R69-R75.

Kwan, E.P., Gao, X., Leung, Y.M., Gaisano, H.Y., 2007. Activation of exchange protein directly activated by cyclic adenosine monophosphate and protein kinase A regulate common and distinct steps in promoting plasma membrane exocytic and granule-togranule fusions in rat islet $\beta$ cells. Pancreas 35, e45-e54.

Landa, L.R., Jr., Harbeck, M., Kaihara, K., Chepurny, O., Kitiphongspattana, K., Graf, O., Nikolaev, V.O., Lohse, M.J., Holz, G.G., Roe, M.W., 2005. Interplay of $\mathrm{Ca}^{2+}$ and cAMP signaling in the insulin-secreting MIN6 $\beta$-cell line. J. Biol. Chem. 280, 31294-31302.

Lang, D.A., Matthews, D.R., Burnett, M., Turner, R.C., 1981. Brief, irregular oscillations of basal plasma insulin and glucose concentrations in diabetic man. Diabetes 30, 435-439. 
Larsson, O., Kindmark, H., Brandström, R., Fredholm, B., Berggren, P.O., 1996. Oscillations in $\mathrm{K}_{\text {ATP }}$ channel activity promote oscillations in cytoplasmic free $\mathrm{Ca}^{2+}$ concentration in the pancreatic $\beta$ cell. Proc. Natl. Acad. Sci. U. S. A. 93, 5161-5165.

Laychock, S.G., 1983. Identification and metabolism of polyphosphoinositides in isolated islets of Langerhans. Biochem. J. 216, 101-106.

Leech, C.A., Castonguay, M.A., Habener, J.F., 1999. Expression of adenylyl cyclase subtypes in pancreatic $\beta$-cells. Biochem. Biophys. Res. Commun. 254, 703-706.

Leibiger, I.B., Leibiger, B., Moede, T., Berggren, P.O., 1998. Exocytosis of insulin promotes insulin gene transcription via the insulin receptor/PI-3 kinase/p70 s6 kinase and CaM kinase pathways. Mol. Cell 1, 933-938.

Leibiger, I.B., Leibiger, B., Berggren, P.O., 2002. Insulin feedback action on pancreatic $\beta$-cell function. FEBS Lett. 532, 1-6.

Lenzen, S., Lerch, M., Peckmann, T., Tiedge, M., 2000. Differential regulation of $\left[\mathrm{Ca}^{2+}\right]_{\mathrm{i}}$ oscillations in mouse pancreatic islets by glucose, $\alpha$-ketoisocaproic acid, glyceraldehyde and glycolytic intermediates. Biochim. Biophys. Acta 1523, 65-72.

Lester, L.B., Langeberg, L.K., Scott, J.D., 1997. Anchoring of protein kinase A facilitates hormone-mediated insulin secretion. Proc. Natl. Acad. Sci. U. S. A. 94, 14942-14947.

Lester, L.B., Faux, M.C., Nauert, J.B., Scott, J.D., 2001. Targeted protein kinase A and PP-2B regulate insulin secretion through reversible phosphorylation. Endocrinology 142, 12181227.

Liu, Y.J., Grapengiesser, E., Gylfe, E., Hellman, B., 1996. Crosstalk between the cAMP and inositol trisphosphate signalling pathways in pancreatic $\beta$-cells. Arch. Biochem. Biophys. 334, 295-302.

Liu, Y.J., Gylfe, E., 1997. Store-operated $\mathrm{Ca}^{2+}$ entry in insulin-releasing pancreatic $\beta$-cells. Cell Calcium 22, 277-286.

Liu, Y.J., Tengholm, A., Grapengiesser, E., Hellman, B., Gylfe, E., 1998. Origin of slow and fast oscillations of $\mathrm{Ca}^{2+}$ in mouse pancreatic islets. J. Physiol. (Lond). 508, 471-481.

Longo, E.A., Tornheim, K., Deeney, J.T., Varnum, B.A., Tillotson, D., Prentki, M., Corkey, B.E., 1991. Oscillations in cytosolic free $\mathrm{Ca}^{2+}$, oxygen consumption, and insulin secretion in glucose-stimulated rat pancreatic islets. J. Biol. Chem. 266, 9314-9319.

Luciani, D.S., Misler, S., Polonsky, K.S., 2006. $\mathrm{Ca}^{2+}$ controls slow NAD(P)H oscillations in glucose-stimulated mouse pancreatic islets. J. Physiol. (London) 572, 379-392.

Lundquist, I., Alm, P., Salehi, A., Henningsson, R., Grapengiesser, E., Hellman, B., 2003. Carbon monoxide stimulates insulin release and propagates $\mathrm{Ca}^{2+}$ signals between pancreatic $\beta$-cells. Am. J. Physiol. Endocrinol. Metab. 285, E1055-E1063.

MacDonald, M.J., Fahien, L.A., Buss, J.D., Hasan, N.M., Fallon, M.J., Kendrick, M.A., 2003. Citrate oscillates in liver and pancreatic beta cell mitochondria and in INS-1 insulinoma cells. J. Biol. Chem. 278, 51894-51900.

MacDonald, P.E., Rorsman, P., 2007. The ins and outs of secretion from pancreatic $\beta$-cells: control of single-vesicle exo- and endocytosis. Physiology (Bethesda) 22, 113-121.

Magnus, G., Keizer, J., 1997. Minimal model of $\beta$-cell mitochondrial $\mathrm{Ca}^{2+}$ handling. American Journal of Physiolgy 273, C717-C733.

Magnus, G., Keizer, J., 1998a. Model of $\beta$-cell mitochondrial calcium handling and electrical activity. II. Mitochondrial variables. Am. J. Physiol. 274, C1174-C1184.

Magnus, G., Keizer, J., 1998b. Model of $\beta$-cell mitochondrial calcium handling and electrical activity. I. Cytoplasmic variables. Am. J. Physiol. 274, C1158-C1173. 
Malaisse, W.J., Sener, A., Herchuelz, A., Carpinelli, A.R., Poloczek, P., Winand, J., Castagna, M., 1980. Insulinotropic effect of the tumor promoter 12-Otetradecanoylphorbol-13-acetate in rat pancreatic islets. Cancer Res. 40, 3827-3831.

Martin, F., Sanchez-Andres, J.V., Soria, B., 1995. Slow $\left[\mathrm{Ca}^{2+}\right]_{i}$ oscillations induced by ketoisocaproate in single mouse pancreatic islets. Diabetes 44, 300-305.

Mathias, P.C., Best, L., Malaisse, W.J., 1985. Stimulation by glucose and carbamylcholine of phospholipase $\mathrm{C}$ in pancreatic islets. Cell Biochem. Funct. 3, 173-177.

Matschinsky, F.M., 1990. Glucokinase as glucose sensor and metabolic signal generator in pancreatic beta-cells and hepatocytes. Diabetes 39, 647-652.

Matthews, D.R., Lang, D.A., Burnett, M.A., Turner, R.C., 1983a. Control of pulsatile insulin secretion in man. Diabetologia 24, 231-237.

Matthews, D.R., Naylor, B.A., Jones, R.G., Ward, G.M., Turner, R.C., 1983b. Pulsatile insulin has greater hypoglycemic effect than continuous delivery. Diabetes 32, 617-621.

Matthews, D.R., 1987. Glucose homeostasis. Biochem. Soc. Trans. 15, 1021-1023.

Matthews, D.R., Hermansen, K., Conolly, A.A., Gray, D., Schmitz, O., Clark, A., Orskov, H., Turner, R.C., 1987. Greater in vivo than in vitro pulsatility of insulin secretion with synchronized insulin and somatostatin secretory pulses. Endocrinology 120, 2272-2278.

McCormack, J.G., Longo, E.A., Corkey, B.E., 1990. Glucose-induced activation of pyruvate dehydrogenase in isolated rat pancreatic islets. Biochem. J. 267, 527-530.

McLaughlin, S., Wang, J., Gambhir, A., Murray, D., 2002. PIP 2 and proteins: interactions, organization, and information flow. Annu. Rev. Biophys. Biomol. Struct. 31, 151-175.

Mendez, C.F., Leibiger, I.B., Leibiger, B., Hoy, M., Gromada, J., Berggren, P.O., Bertorello, A.M., 2003. Rapid association of protein kinase C- $\varepsilon$ with insulin granules is essential for insulin exocytosis. J. Biol. Chem. 278, 44753-44757.

Metz, S.A., 1988. Perspectives in diabetes. Is protein kinase $\mathrm{C}$ required for physiologic insulin release? Diabetes 37, 3-7.

Michael, D.J., Xiong, W., Geng, X., Drain, P., Chow, R.H., 2007. Human insulin vesicle dynamics during pulsatile secretion. Diabetes 56, 1277-1288.

Milner, R.D.G., Hales, C.N., 1967. The role of calcium and magnesium in insulin secretion from rabbit pancreas studied in vitro. Diabetologia 3, 47-49.

Miura, Y., Gilon, P., Henquin, J.C., 1996. Muscarinic stimulation increases $\mathrm{Na}^{+}$entry in pancreatic B-cells by a mechanism other than the emptying of intracellular $\mathrm{Ca}^{2+}$ pools. Biochem. Biophys. Res. Commun. 224, 67-73.

Miura, Y., Henquin, J.C., Gilon, P., 1997. Emptying of intracellular $\mathrm{Ca}^{2+}$ stores stimulates $\mathrm{Ca}^{2+}$ entry in mouse pancreatic $\beta$-cells by both direct and indirect mechanisms. J. Physiol. (Lond). 503, 387-398.

Montague, W., Morgan, N.G., Rumford, G.M., Prince, C.A., 1985. Effect of glucose on polyphosphoinositide metabolism in isolated rat islets of Langerhans. Biochem. J. 227, 483-489.

Muller, D., Huang, G.C., Amiel, S., Jones, P.M., Persaud, S.J., 2006. Identification of insulin signaling elements in human $\beta$-cells: autocrine regulation of insulin gene expression. Diabetes 55, 2835-2842.

Nenquin, M., Szollosi, A., Aguilar-Bryan, L., Bryan, J., Henquin, J.C., 2004. Both triggering and amplifying pathways contribute to fuel-induced insulin secretion in the absence of sulfonylurea receptor-1 in pancreatic $\beta$-cells. J. Biol. Chem. 279, 32316-32324. 
Nunemaker, C.S., Zhang, M., Satin, L.S., 2004. Insulin feedback alters mitochondrial activity through an ATP-sensitive $\mathrm{K}^{+}$channel-dependent pathway in mouse islets and $\beta$-cells. Diabetes 53, 1765-1772.

O'Rahilly, S., Turner, R.C., Matthews, D.R., 1988. Impaired pulsatile secretion of insulin in relatives of patients with non-insulin-dependent diabetes. N. Engl. J. Med. 318, 1225-1230.

Ohsugi, M., Cras-Meneur, C., Zhou, Y., Bernal-Mizrachi, E., Johnson, J.D., Luciani, D.S., Polonsky, K.S., Permutt, M.A., 2005. Reduced expression of the insulin receptor in mouse insulinoma (MIN6) cells reveals multiple roles of insulin signaling in gene expression, proliferation, insulin content, and secretion. J. Biol. Chem. 280, 4992-5003.

Okada, T., Liew, C.W., Hu, J., Hinault, C., Michael, M.D., Krtzfeldt, J., Yin, C., Holzenberger, M., Stoffel, M., Kulkarni, R.N., 2007. Insulin receptors in $\beta$-cells are critical for islet compensatory growth response to insulin resistance. Proc. Natl. Acad. Sci. U. S. A. $104,8977-8982$.

Olsen, H.L., Høy, M., Zhang, W., Bertorello, A.M., Bokvist, K., Capito, K., Efanov, A.M., Meister, B., Thams, P., Yang, S.N., Rorsman, P., Berggren, P.O., Gromada, J., 2003. Phosphatidylinositol 4-kinase serves as a metabolic sensor and regulates priming of secretory granules in pancreatic $\beta$ cells. Proc. Natl. Acad. Sci. U. S. A. 100, 5187-5192.

Ortsäter, H., Liss, P., Lund, P.E., Åkerman, K.E., Bergsten, P., 2000. Oscillations in oxygen tension and insulin release of individual pancreatic ob/ob mouse islets. Diabetologia 43, $1313-1318$.

Ozaki, N., Shibasaki, T., Kashima, Y., Miki, T., Takahashi, K., Ueno, H., Sunaga, Y., Yano, H., Matsuura, Y., Iwanaga, T., Takai, Y., Seino, S., 2000. cAMP-GEFII is a direct target of cAMP in regulated exocytosis. Nat. Cell Biol. 2, 805-811.

Panten, U., Christians, J., Kriegstein, E.v., Poser, W., Hasselblatt, A., 1973. Effect of carbohydrates upon fluorescence of reduced pyridine nucleotides from perifused isolated pancreatic islets. Diabetologia 9, 477-482.

Paolisso, G., Sgambato, S., Gentile, S., Memoli, P., Giugliano, D., Varricchio, M., D'Onofrio, F., 1988a. Advantageous metabolic effects of pulsatile insulin delivery in noninsulindependent diabetic patients. J. Clin. Endocrinol. Metab. 67, 1005-1010.

Paolisso, G., Sgambato, S., Torella, R., Varricchio, M., Scheen, A.J., D'Onofrio, F., Lefèbvre, P.J., 1988b. Pulsatile insulin delivery is more efficient than continuous infusion in modulating islet cell function in normal subjects and patients with type 1 diabetes. J. Clin. Endocrinol. Metab. 66, 1220-1226.

Patel, Y.C., Amherdt, M., Orci, L., 1982. Quantitative electron microscopic autoradiography of insulin, glucagon, and somatostatin binding sites on islets. Science 217, 1155-1156.

Persaud, S.J., Asare-Anane, H., Jones, P.M., 2002. Insulin receptor activation inhibits insulin secretion from human islets of Langerhans. FEBS Lett. 510, 225-258.

Peter-Riesch, B., Fathi, M., Schlegel, W., Wollheim, C.B., 1988. Glucose and carbachol generate 1,2-diacylglycerols by different mechanisms in pancreatic islets. J. Clin. Invest. 81, 1154-1161.

Pinton, P., Tsuboi, T., Ainscow, E.K., Pozzan, T., Rizzuto, R., Rutter, G.A., 2002. Dynamics of glucose-induced membrane recruitment of protein kinase $C \beta I I$ in living pancreatic islet $\beta$-cells. J. Biol. Chem. 277, 37702-37710.

Pitter, J.G., Maechler, P., Wollheim, C.B., Spat, A., 2002. Mitochondria respond to $\mathrm{Ca}^{2+}$ already in the submicromolar range: correlation with redox state. Cell Calcium 31, 97-104. 
Pørksen, N., Munn, S., Steers, J., Vore, S., Veldhuis, J., Butler, P., 1995. Pulsatile insulin secretion accounts for $70 \%$ of total insulin secretion during fasting. Am. J. Physiol. 269, E478-E488.

Pørksen, N., Munn, S., Steers, J., Veldhuis, J.D., Butler, P.C., 1996. Effects of glucose ingestion versus infusion on pulsatile insulin secretion. The incretin effect is achieved by amplification of insulin secretory burst mass. Diabetes 45, 1317-1323.

Pørksen, N., Nyholm, B., Veldhuis, J.D., Butler, P.C., Schmitz, O., 1997. In humans at least $75 \%$ of insulin secretion arises from punctuated insulin secretory bursts. Am. J. Physiol. 273, E908-E914.

Pørksen, N., Grofte, B., Nyholm, B., Holst, J.J., Pincus, S.M., Veldhuis, J.D., Schmitz, O., Butler, P.C., 1998. Glucagon-like peptide 1 increases mass but not frequency or orderliness of pulsatile insulin secretion. Diabetes 47, 45-49.

Pørksen, N., 2002. The in vivo regulation of pulsatile insulin secretion. Diabetologia 45, 3-20.

Pralong, W.F., Spät, A., Wollheim, C.B., 1994. Dynamic pacing of cell metabolism by intracellular $\mathrm{Ca}^{2+}$ transients. J. Biol. Chem. 269, 27310-27314.

Prentki, M., Glennon, M.C., Geschwind, J.F., Matschinsky, F.M., Corkey, B.E., 1987. Cyclic AMP raises cytosolic $\mathrm{Ca}^{2+}$ and promotes $\mathrm{Ca}^{2+}$ influx in a clonal pancreatic $\beta$-cell line (HIT T-15). FEBS Lett. 220, 103-107.

Prentki, M., Matschinsky, F.M., 1987. $\mathrm{Ca}^{2+}$, cAMP, and phospholipid-derived messengers in coupling mechanisms of insulin secretion. Physiol. Rev. 67, 1185-1248.

Prentki, M., Glennon, M.C., Thomas, A.P., Morris, R.L., Matschinsky, F.M., Corkey, B.E., 1988. Cell-specific patterns of oscillating free $\mathrm{Ca}^{2+}$ in carbamylcholine-stimulated insulinoma cells. J. Biol. Chem. 263, 11044-11047.

Pyne, N.J., Furman, B.L., 2003. Cyclic nucleotide phosphodiesterases in pancreatic islets. Diabetologia 46, 1179-1189.

Qian, W.J., Peters, J.L., Dahlgren, G.M., Gee, K.R., Kennedy, R.T., 2004. Simultaneous monitoring of $\mathrm{Zn}^{2+}$ secretion and intracellular $\mathrm{Ca}^{2+}$ from islets and islet cells by fluorescence microscopy. Biotechniques 37, 922-4, 926, 928-30 passim.

Randle, P.J., Ashcroft, S.J.H., Gill, J.R., 1968. Carbohydrate metabolism and release of hormones. In: Dickens, F. et al. eds.), Carbohydrate metabolism and its disorders. Academic Press, London, pp. 427-447.

Ravier, M.A., Güldenagel, M., Charollais, A., Gjinovci, A., Caille, D., Söhl, G., Wollheim, C.B., Willecke, K., Henquin, J.C., Meda, P., 2005. Loss of connexin36 channels alters $\beta$ cell coupling, islet synchronization of glucose-induced $\mathrm{Ca}^{2+}$ and insulin oscillations, and basal insulin release. Diabetes 54, 1798-1807.

Renström, E., Eliasson, L., Rorsman, P., 1997. Protein kinase A-dependent and -independent stimulation of exocytosis by cAMP in mouse pancreatic B-cells. J. Physiol. (Lond). 502, 105-118.

Richard, A.M., Webb, D.L., Goodman, J.M., Schultz, V., Flanagan, J.N., Getty-Kaushik, L., Deeney, J.T., Yaney, G.C., Dunaway, G.A., Berggren, P.O., Tornheim, K., 2007. Tissuedependent loss of phosphofructokinase-M in mice with interrupted activity of the distal promoter: impairment in insulin secretion. Am. J. Physiol. Endocrinol. Metab. 293, E794E801.

Ritzel, R., Schulte, M., Pørksen, N., Nauck, M.S., Holst, J.J., Juhl, C., Marz, W., Schmitz, O., Schmiegel, W.H., Nauck, M.A., 2001. Glucagon-like peptide 1 increases secretory burst 
mass of pulsatile insulin secretion in patients with type 2 diabetes and impaired glucose tolerance. Diabetes 50, 776-784.

Rorsman, P., Renström, E., 2003. Insulin granule dynamics in pancreatic beta cells. Diabetologia 46, 1029-1045.

Rothenberg, P.L., Willison, L.D., Simon, J., Wolf, B.A., 1995. Glucose-induced insulin receptor tyrosine phosphorylation in insulin-secreting $\beta$-cells. Diabetes 44, 802-809.

Rutter, G.A., 1999. Insulin secretion: feed-forward control of insulin biosynthesis? Curr. Biol. 9, R443-R445.

Saha, S., Hellman, B., 1991. Carbachol has opposite effects to glucose in raising the sodium content of pancreatic islets. Eur. J. Pharmacol. 204, 211-215.

Salehi, A., Qader, S.S., Grapengiesser, E., Hellman, B., 2005. Inhibition of purinoceptors amplifies glucose-stimulated insulin release with removal of its pulsatility. Diabetes 54, 2126-2131.

Salehi, A., Vieira, E., Gylfe, E., 2006. Paradoxical stimulation of glucagon secretion by high glucose concentrations. Diabetes 55, 2318-2323.

Santos, R.M., Rosario, L.M., Nadal, A., Garcia-Sancho, J., Soria, B., Valdeolmillos, M., 1991. Widespread synchronous $\left[\mathrm{Ca}^{2+}\right]_{\mathrm{i}}$ oscillations due to bursting electrical activity in single pancreatic islets. Pflügers Arch. 418, 417-422.

Schmitz-Peiffer, C., Laybutt, D.R., Burchfield, J.G., Gurisik, E., Narasimhan, S., Mitchell, C.J., Pedersen, D.J., Braun, U., Cooney, G.J., Leitges, M., Biden, T.J., 2007. Inhibition of $\mathrm{PKC} \varepsilon$ improves glucose-stimulated insulin secretion and reduces insulin clearance. Cell Metabolism 6, 320-328.

Schrey, M.P., Montague, W., 1983. Phosphatidylinositol hydrolysis in isolated guinea-pig islets of Langerhans. Biochem. J. 216, 433-441.

Schuit, F.C., Pipeleers, D.G., 1985. Regulation of adenosine 3',5' monophosphate levels in the pancreatic $\beta$-cell. Endocrinology 117, 834-840.

Sehlin, J., Täljedal, I.B., 1975. Glucose-induced decrease in $\mathrm{Rb}^{+}$permeability in pancreatic $\beta$ cells. Nature 253, 635-636.

Seino, S., Shibasaki, T., 2005. PKA-dependent and PKA-independent pathways for cAMPregulated exocytosis. Physiol. Rev. 85, 1303-1342.

Sharp, G.W., 1979. The adenylate cyclase-cyclic AMP system in islets of Langerhans and its role in the control of insulin release. Diabetologia 16, 287-296.

Shibasaki, T., Sunaga, Y., Fujimoto, K., Kashima, Y., Seino, S., 2004. Interaction of ATP sensor, cAMP sensor, $\mathrm{Ca}^{2+}$ sensor, and voltage-dependent $\mathrm{Ca}^{2+}$ channel in insulin granule exocytosis. J. Biol. Chem. 279, 7956-7961.

Shibasaki, T., Takahashi, H., Miki, T., Sunaga, Y., Matsumura, K., Yamanaka, M., Zhang, C., Tamamoto, A., Satoh, T., Miyazaki, J., Seino, S., 2007. Essential role of Epac2/Rap1 signaling in regulation of insulin granule dynamics by cAMP. Proc. Natl. Acad. Sci. U. S. A. 104, 19333-19338.

Shyng, S.L., Nichols, C.G., 1998. Membrane phospholipid control of nucleotide sensitivity of $\mathrm{K}_{\text {ATP }}$ channels. Science 282, 1138-1141.

Stagner, J.I., Samols, E., Weir, G.C., 1980. Sustained oscillations of insulin glucagon and somatostatin from the isolated canine pancreas during exposure to a constant glucose concentration. J. Clin. Invest. 65, 939-942.

Stagner, J.I., Samols, E., 1985a. Perturbation of insulin oscillations by nerve blockade in the in vitro canine pancreas. Am. J. Physiol. 248, E516-E521. 
Stagner, J.I., Samols, E., 1985b. Role of intrapancreatic ganglia in regulation of periodic insular secretions. Am. J. Physiol. 248, E522-E530.

Storch, M.J., Rössle, M., Kerp, L., 1993. Pulsatile Insulinsekretion in die Pfortader bei Leberzirrhose. Dtsch. Med. Wochenschr. 118, 134-138.

Suzuki, Y., Zhang, H., Saito, N., Kojima, I., Urano, T., Mogami, H., 2006. Glucagon-like peptide 1 activates protein kinase $\mathrm{C}$ through $\mathrm{Ca}^{2+}$-dependent activation of phospholipase $\mathrm{C}$ in insulin-secreting cells. J. Biol. Chem. 281, 28499-28507.

Szollosi, A., Nenquin, M., Aguilar-Bryan, L., Bryan, J., Henquin, J.C., 2007. Glucose stimulates $\mathrm{Ca}^{2+}$ influx and insulin secretion in 2-week-old $\beta$-cells lacking ATP-sensitive $\mathrm{K}^{+}$ channels. J. Biol. Chem. 282, 1747-1756.

Tamagawa, T., Niki, H., Niki, A., 1985. Insulin release independent of a rise in cytosolic free $\mathrm{Ca}^{2+}$ by forskolin and phorbol ester. FEBS Lett. 183, 430-432.

Tamarina, N.A., Kuznetsov, A., Rhodes, C.J., Bindokas, V.P., Philipson, L.H., 2005. Inositol $(1,4,5)$-trisphosphate dynamics and intracellular calcium oscillations in pancreatic $\beta$-cells. Diabetes 54, 3073-3081.

Tengholm, A., Hellman, B., Gylfe, E., 1999. Glucose regulation of free $\mathrm{Ca}^{2+}$ in the endoplasmatic reticulum of mouse pancreatic beta cells. J. Biol. Chem. 274, 36883-36890.

Theler, J.M., Mollard, P., Guérineau, N., Vacher, P., Pralong, W.F., Schlegel, W., Wollheim, C.B., 1992. Video imaging of cytosolic $\mathrm{Ca}^{2+}$ in pancreatic $\beta$-cells stimulated by glucose, carbachol and ATP. J. Biol. Chem. 267, 18110-18117.

Thore, S., Dyachok, O., Tengholm, A., 2004. Oscillations of phospholipase C activity triggered by depolarization and $\mathrm{Ca}^{2+}$ influx in insulin-secreting cells. J. Biol. Chem. 279, 19396-19400.

Thore, S., Dyachok, O., Gylfe, E., Tengholm, A., 2005. Feedback activation of phospholipase $\mathrm{C}$ via intracellular mobilization and store-operated influx of $\mathrm{Ca}^{2+}$ in insulin-secreting $\beta$ cells. J. Cell Sci. 118, 4463-4471.

Thore, S., Wuttke, A., Tengholm, A., 2007. Rapid turnover of phosphatidylinositol-4,5bisphosphate in insulin-secreting cells mediated by $\mathrm{Ca}^{2+}$ and the ATP-to-ADP ratio. Diabetes 56, 818-826.

Thorens, B., Guillam, M.T., Beermann, F., Burcelin, R., Jaquet, M., 2000. Transgenic reexpression of GLUT1 or GLUT2 in pancreatic beta cells rescues GLUT2-null mice from early death and restores normal glucose-stimulated insulin secretion. J. Biol. Chem. 275, 23751-23758.

Tornheim, K., 1997. Are metabolic oscillations responsible for normal oscillatory insulin secretion? Diabetes 46, 1375-1380.

Uchida, T., Iwashita, N., Ohara-Imaizumi, M., Ogihara, T., Nagai, S., Choi, J.B., Tamura, Y., Tada, N., Kawamori, R., Nakayama, K.I., Nagamatsu, S., Watada, H., 2007. Protein kinase $\mathrm{C} \delta$ plays a non-redundant role in insulin secretion in pancreatic $\beta$ cells. J. Biol. Chem. 282, 2707-2716.

Valdeolmillos, M., Gomis, A., Sanchez-Andres, J.V., 1996. In vivo synchronous membrane potential oscillations in mouse pancreatic $\beta$-cells: lack of co-ordination between islets. J. Physiol. (Lond). 493, 9-18.

Valverde, I., Vandermeers, A., Anjaneyulu, R., Malaisse, W.J., 1979. Calmodulin activation of adenylate cyclase in pancreatic islets. Science 206, 225-227. 
Varadi, A., Ainscow, E.K., Allan, V.J., Rutter, G.A., 2002. Involvement of conventional kinesin in glucose-stimulated secretory granule movements and exocytosis in clonal pancreatic $\beta$-cells. J. Cell Sci. 115, 4177-4189.

Varadi, A., Tsuboi, T., Johnson-Cadwell, L.I., Allan, V.J., Rutter, G.A., 2003. Kinesin I and cytoplasmic dynein orchestrate glucose-stimulated insulin-containing vesicle movements in clonal MIN6 $\beta$-cells. Biochem. Biophys. Res. Commun. 311, 272-282.

Varadi, A., Tsuboi, T., Rutter, G.A., 2005. Myosin Va transports dense core secretory vesicles in pancreatic MIN6 $\beta$-cells. Mol. Biol. Cell 16, 2670-2680.

Varnai, P., Balla, T., 2006. Live cell imaging of phosphoinositide dynamics with fluorescent protein domains. Biochim. Biophys. Acta 1761, 957-967.

Velloso, L.A., Carneiro, E.M., Crepaldi, S.C., Boschero, A.C., Saad, M.J., 1995. Glucoseand insulin-induced phosphorylation of the insulin receptor and its primary substrates IRS1 and IRS-2 in rat pancreatic islets. FEBS Lett. 377, 353-357.

Verspohl, E.J., Ammon, H.P., 1980. Evidence for presence of insulin receptors in rat islets of Langerhans. J. Clin. Invest. 65, 1230-1237.

Virji, M.A., Steffes, M.W., Estensen, R.D., 1978. Phorbol myristate acetate: effect of a tumor promoter on insulin release from isolated rat islets of Langerhans. Endocrinology 102, 706711.

Warwar, N., Efendic, S., Ostenson, C.G., Haber, E.P., Cerasi, E., Nesher, R., 2006. Dynamics of glucose-induced localization of PKC isoenzymes in pancreatic $\beta$-cells: diabetes-related changes in the GK rat. Diabetes 55, 590-599.

Waselle, L., Gerona, R.R., Vitale, N., Martin, T.F., Bader, M.F., Regazzi, R., 2005. Role of phosphoinositide signaling in the control of insulin exocytosis. Mol. Endocrinol. 19, 30973106.

Westerlund, J., Hellman, B., Bergsten, P., 1996. Pulsatile insulin release from mouse islets occurs in the absence of stimulated entry of $\mathrm{Ca}^{2+}$. J. Clin. Invest. 97, 1860-1863.

Westerlund, J., Gylfe, E., Bergsten, P., 1997. Pulsatile insulin release from pancreatic islets with non-oscillatory elevation of cytoplasmic $\mathrm{Ca}^{2+}$. J. Clin. Invest. 100, 2547-2551.

Westerlund, J., Wolf, B.A., Bergsten, P., 2002. Glucose-dependent promotion of insulin release from mouse pancreatic islets by the insulin-mimetic compound L-783,281. Diabetes 51 Suppl 1, S50-S52.

Willoughby, D., Cooper, D.M., 2007. Organization and $\mathrm{Ca}^{2+}$ regulation of adenylyl cyclases in cAMP microdomains. Physiol. Rev. 87, 965-1010.

Wiser, O., Trus, M., Hernandez, A., Renström, E., Barg, S., Rorsman, P., Atlas, D., 1999. The voltage sensitive Lc-type $\mathrm{Ca} 2+$ channel is functionally coupled to the exocytotic machinery. Proc. Natl. Acad. Sci. U. S. A. 96, 248-253.

Withers, D.J., Gutierrez, J.S., Towery, H., Burks, D.J., Ren, J.M., Previs, S., Zhang, Y., Bernal, D., Pons, S., Shulman, G.I., Bonner-Weir, S., White, M.F., 1998. Disruption of IRS-2 causes type 2 diabetes in mice. Nature 391, 900-904.

Wolf, B.A., Easom, R.A., Hughes, J.H., McDaniel, M.L., Turk, J., 1989. Secretagogueinduced diacylglycerol accumulation in isolated pancreatic islets. Mass spectrometric characterization of the fatty acyl content indicates multiple mechanisms of generation. Biochemistry (Mosc). 28, 4291-4301.

Wollheim, C.B., Sharp, G.W.G., 1981. Regulation of insulin release by calcium. Physiol. Rev. 61, 914-973. 
Worley, J.F., III, McIntyre, M.S., Spencer, B., Dukes, I.D., 1994a. Depletion of intracellular $\mathrm{Ca}^{2+}$ stores activates a maitotoxin-sensitive nonselective cationic current in $\beta$-cells. J. Biol. Chem. 269, 32055-32058.

Worley, J.F., III, McIntyre, M.S., Spencer, B., Mertz, R.J., Roe, M.W., Dukes, I.D., 1994b. Endoplasmic reticulum calcium store regulates membrane potential in mouse islet $\beta$-cells. J. Biol. Chem. 269, 14359-14362.

Wu, H., MacFarlane, W.M., Tadayyon, M., Arch, J.R., James, R.F., Docherty, K., 1999. Insulin stimulates pancreatic-duodenal homoeobox factor-1 (PDX1) DNA-binding activity and insulin promoter activity in pancreatic $\beta$ cells. Biochem. J. 344, 813-818.

$\mathrm{Xu}$, G.G., Rothenberg, P.L., 1998. Insulin receptor signaling in the $\beta$-cell influences insulin gene expression and insulin content: evidence for autocrine $\beta$-cell regulation. Diabetes 47 , 1243-1252.

Xu, G.G., Gao, Z.Y., Borge, P.D., Jr., Wolf, B.A., 1999. Insulin receptor substrate 1-induced inhibition of endoplasmic reticulum $\mathrm{Ca}^{2+}$ uptake in $\beta$-cells. Autocrine regulation of intracellular $\mathrm{Ca}^{2+}$ homeostasis and insulin secretion. J. Biol. Chem. 274, 18067-18074.

Xu, G.G., Gao, Z.Y., Borge, P.D., Jr., Jegier, P.A., Young, R.A., Wolf, B.A., 2000. Insulin regulation of $\beta$-cell function involves a feedback loop on SERCA gene expression, $\mathrm{Ca}^{2+}$ homeostasis, and insulin expression and secretion. Biochemistry (Mosc). 39, 14912-14919.

Yamazaki, H., Philbrick, W., Zawalich, K.C., Zawalich, W.S., 2006a. Acute and chronic effects of glucose and carbachol on insulin secretion and phospholipase $\mathrm{C}$ activation: studies with diazoxide and atropine. Am. J. Physiol. Endocrinol. Metab. 290, E26-E33.

Yamazaki, H., Zawalich, K.C., Zawalich, W.S., 2006b. Desensitization of the pancreatic $\beta-$ cell: effects of sustained physiological hyperglycemia and potassium. Am. J. Physiol. Endocrinol. Metab. 291, H1381-H1387.

Yu, J., Berggren, P.O., Barker, C.J., 2007. An autocrine insulin feedback loop maintains pancreatic $\beta$-cell 3-phosphorylated inositol lipids. Mol. Endocrinol. 21, 2775-2784.

Zawalich, W.S., Zawalich, K.C., 1988. Induction of memory in rat pancreatic islets by tolbutamide. Dependence on ambient glucose level, calcium, and phosphoinositide hydrolysis. Diabetes 37, 816-823.

Zawalich, W.S., Zawalich, K.C., Kelley, G.G., 1995. Regulation of insulin release by phospholipase $\mathrm{C}$ activation in mouse islets: differential effects of glucose and neurohumoral stimulation. Endocrinology 136, 4903-4909.

Zawalich, W.S., Zawalich, K.C., 1996. Regulation of insulin secretion by phospholipase C. American Journal of Physiolgy 271, E409-E416.

Zawalich, W.S., Zawalich, K.C., 2000. A link between insulin resistance and hyperinsulinemia: inhibitors of phosphatidylinositol 3-kinase augment glucose-induced insulin secretion from islets of lean, but not obese, rats. Endocrinology 141, 3287-3295.

Zawalich, W.S., Tesz, G.J., Yamazaki, H., Zawalich, K.C., Philbrick, W., 2006. Dexamethasone suppresses phospholipase $\mathrm{C}$ activation and insulin secretion from isolated rat islets. Metabolism. 55, 35-42.

Zhang, H., Nagasawa, M., Yamada, S., Mogami, H., Suzuki, Y., Kojima, I., 2004. Bimodal role of conventional protein kinase $\mathrm{C}$ in insulin secretion from rat pancreatic beta cells. $\mathrm{J}$ Physiol 561, 133-47. 
Table 1. Characteristics of different types of $\left[\mathrm{Ca}^{2+}\right]_{\mathrm{i}}$ oscillations in single $\beta$-cells and isolated pancreatic islets.

\begin{tabular}{|c|c|c|c|c|c|c|c|}
\hline $\begin{array}{c}\text { Type of }\left[\mathrm{Ca}^{2+}\right]_{\mathbf{i}} \\
\text { oscillation }\end{array}$ & Preparation & Frequency & $\begin{array}{c}\text { Duration of } \\
\text { each }\left[\mathrm{Ca}^{2+}\right]_{i} \\
\text { increase }\end{array}$ & $\begin{array}{c}\text { Glucose } \\
\text { dependence }\end{array}$ & $\begin{array}{c}\text { Dependence on } \\
\text { voltage- } \\
\text { operated } \mathrm{Ca}^{2+} \\
\text { influx }\end{array}$ & $\begin{array}{c}\text { Dependence on } \\
\text { intracellular } \\
\mathrm{Ca}^{2+} \text { uptake } \\
\text { and release } \\
\end{array}$ & Main stimuli \\
\hline Slow & single & $0.1-0.5 \mathrm{~min}^{-1}$ & $1-5 \min$ & $\begin{array}{l}\text { threshold for } \\
\text { induction }\end{array}$ & essential & $\begin{array}{l}\text { not required, but } \\
\text { shaping effect }\end{array}$ & $\begin{array}{l}\text { glucose, leucine, } \\
\text { tolbutamide }\end{array}$ \\
\hline Slow & is & $0.15-0.3 \mathrm{~min}^{-1}$ & $1-5 \min$ & $\begin{array}{l}\text { threshold for } \\
\text { induction }\end{array}$ & essential & $\begin{array}{l}\text { not required, but } \\
\text { shaping effect }\end{array}$ & $\begin{array}{l}\text { glucose, leucine, } \\
\text { tolbutamide }\end{array}$ \\
\hline Fast & islets & $1-5 \min ^{-1}$ & $<40 \mathrm{~s}$ & $\begin{array}{l}\text { strong effect on } \\
\text { duration above } \\
\text { threshold }\end{array}$ & essential & $\begin{array}{c}\text { some } \\
\text { dependence }\end{array}$ & glucose \\
\hline Spiking & $\begin{array}{l}\text { single } \beta \text {-cells } \\
\text { and islets }\end{array}$ & often irregular & $<40 \mathrm{~s}$ & $\begin{array}{l}\text { graded above } \\
\text { threshold }\end{array}$ & $\begin{array}{l}\text { not required, but } \\
\text { stimulating }\end{array}$ & $\begin{array}{c}\text { essential, } \\
\text { mediated by } \mathrm{IP}_{3} \\
\text { and cAMP }\end{array}$ & $\begin{array}{c}\text { cAMP-elevating } \\
\text { agents }\end{array}$ \\
\hline $\begin{array}{l}\text { Fast receptor- } \\
\text { induced }\end{array}$ & $\begin{array}{l}\text { single } \beta \text {-cells } \\
\text { and islets }\end{array}$ & $1-6 \min ^{-1}$ & $<40 \mathrm{~s}$ & graded & independent & $\begin{array}{c}\text { essential, } \\
\text { mediated by } \mathrm{IP}_{3}\end{array}$ & $\begin{array}{l}\text { phospholipase } \\
\text { C-activating } \\
\text { receptor } \\
\text { agonists } \\
\end{array}$ \\
\hline
\end{tabular}




\section{Figure legends}

Fig. 1. Pulsatile insulin secretion at different organizational levels. The upper panel shows a recording of insulin concentration in the portal vein of the perfused rat pancreas (adopted from Salehi et al 2005). Pulsatile insulin secretion from the pancreas requires coordination of the secretory activity of the individual islets via intrapancreatic nerves and diffusible factors. The middle panel shows insulin secretion from an isolated pancreatic islet (adopted from Bergsten et al., 1994). The synchronization of the oscillations in individual $\beta$-cells via gap junctions and diffusible factors is a prerequisite for pulsatility at this level. The bottom panel illustrates pulsatile insulin secretion from an individual $\beta$-cell recorded with a fluorescent biosensor for autocrine activation of insulin receptors (Idevall-Hagren \& Tengholm, 2006).

Fig. 2. Cytoplasmic $\mathrm{Ca}^{2+}$ oscillations and electrical activity in individual $\beta$-cells. (A) Elevation of the glucose concentration from 3 to $11 \mathrm{mM}$ results in a small initial lowering followed by a pronounced rise and oscillations of $\left[\mathrm{Ca}^{2+}\right]_{\mathrm{i}}$ with a period of 2-10 min in a single mouse $\beta$-cell as measured with the $\mathrm{Ca}^{2+}$ indicator fura-2. (B) In addition to the slow $\left[\mathrm{Ca}^{2+}\right]_{\mathrm{i}}$ oscillations, glucose triggers rapid $\left[\mathrm{Ca}^{2+}\right]_{\mathrm{i}}$ spikes superimposed on the slow oscillations. These spikes become more frequent after exposure of the cells to cAMP-elevating agents. The traces show $\left[\mathrm{Ca}^{2+}\right]_{\mathrm{i}}$ recordings with fura- 2 from two separate cells exposed to $20 \mathrm{mM}$ glucose and 20 $\mathrm{nM}$ glucagon (modified from Grapengiesser et al., 2004). It is notable that both the slow oscillations and the spikes are synchronized between the cells, although they are not in physical contact. (C) The slow $\left[\mathrm{Ca}^{2+}\right]_{\mathrm{i}}$ oscillations correlate with bursts of action currents in a single mouse $\beta$-cell exposed to $11 \mathrm{mM}$ glucose. The top trace shows action currents recorded with the cell-attached configuration of the patch-clamp technique. The middle trace show the 
frequency of the action currents and the lower trace show $\left[\mathrm{Ca}^{2+}\right]_{\mathrm{i}}$ measured with fura-2. (D) Rapid spikes of $\left[\mathrm{Ca}^{2+}\right]_{\mathrm{i}}$ are associated with interruptions of the action currents, probably as a result of the activation of a hyperpolarizing current. (C) and (D) are adopted from Dryselius et al. (1999).

Fig. 3. Dynamic single-cell recordings of phospholipase $\mathrm{C}$ activity using evanescent wave fluorescence microscopy. (A) Fusion of GFP with the $\mathrm{PIP}_{2}$ - and $\mathrm{IP}_{3}$-binding $\mathrm{PH}$ domain from PLC $\delta$, generates a biosensor that is associated with $\mathrm{PIP}_{2}$ in the plasma membrane under basal conditions and which dissociates when this lipid is hydrolyzed by PLC and the concentration of $\mathrm{IP}_{3}$ increases in the cytoplasm. In evanescent wave microscopy, fluorescent molecules are excited within $\sim 100 \mathrm{~nm}$ from the plasma membrane by total internal internal reflection of a laser beam at the interface between a cover slip and the aqueous medium bathing the adherent cells. Fluorescent biosensor binding to the plasma membrane is associated with bright fluorescence, whereas the translocation to the cytoplasm is recorded as loss of fluorescence. (B) Schematic drawing of the control of PLC activity by $\mathrm{Ca}^{2+}$. Agonist (A) activation of a Gprotein coupled receptor (GPCR) results in partial activation of PLC via the Gq family of Gproteins. The resulting hydrolysis of $\mathrm{PIP}_{2}$ leads to formation of diacylglycerol (DAG) and sufficient amounts of $\mathrm{IP}_{3}$ to mobilize $\mathrm{Ca}^{2+}$ via $\mathrm{IP}_{3}$-receptors $\left(\mathrm{IP}_{3} \mathrm{R}\right)$ from the ER. The subsequent elevation of $\left[\mathrm{Ca}^{2+}\right]_{\mathrm{i}}$ feedback activates PLC, which generates more $\mathrm{IP}_{3}$ and so forth. The reduced luminal $\mathrm{Ca}^{2+}$ concentration in the ER activates store-operated channels (SOC) in the plasma membrane and the resulting influx of $\mathrm{Ca}^{2+}$ stimulates PLC activity during sustained receptor stimulation. PLC can also be directly activated by membrane depolarization (depol) and $\mathrm{Ca}^{2+}$ influx via voltage-dependent $\mathrm{Ca}^{2+}$ channels (VOC). (C) 
Simultaneous measurements of $\left[\mathrm{Ca}^{2+}\right]_{\mathrm{i}}$ (black) and membrane $\mathrm{PIP}_{2}$ concentration (green) in a MIN6 cell using the $\mathrm{Ca}^{2+}$ indicator Fura Red and the biosensor PLC $\delta$ PH-GFP. Elevation of glucose triggers oscillations of $\left[\mathrm{Ca}^{2+}\right]_{\mathrm{i}}$ that coincides with loss of $\mathrm{PIP}_{2}$ (activation of PLC). Adopted from Thore et al. (2007). (D) Glucose does not affect PLC activity when voltagedependent $\mathrm{Ca}^{2+}$ influx is prevented by the hyperpolarizing agent diazoxide. Removal of this agent immediately leads to translocation of the biosensor, reinforcing the importance of $\mathrm{Ca}^{2+}$ for glucose activation of PLC.

Fig. 4. GLP-1-induced cAMP oscillations in single insulin-secreting cells measured with a fluorescent translocation reporter and ratiometric evanescent wave microscopy. Increases of reporter fluorescence ratio correspond to increases in cAMP concentration. (A) Stimulation of INS-1 cells with $1 \mathrm{nM}$ GLP-1 in the presence of $3 \mathrm{mM}$ glucose evokes oscillations of cAMP that disappears upon removal of extracellular $\mathrm{Ca}^{2+}$. (B) Simultaneous recording of cAMP (green) and $\left[\mathrm{Ca}^{2+}\right]_{\mathrm{i}}$ (black) in a single INS-1 cell reveals that the GLP-1-induced cAMP oscillations are perfectly synchronized with oscillations of $\left[\mathrm{Ca}^{2+}\right]_{\mathrm{i}}$. Adopted from Dyachok et al. (2006).

Fig. 5. Glucose-induced oscillations of plasma membrane $\mathrm{PIP}_{3}$ concentration. Evanescent wave microscopy recordings from individual MIN6 cells expressing a $\mathrm{PIP}_{3}$-binding GFP construct $\left(\mathrm{GFP}_{4}-\mathrm{GRP} 1\right)$ that translocates to the membrane upon PI3-kinase-catalyzed formation of the lipid. This translocation is recorded as an increase of fluorescence. (A) Elevation of the glucose concentration from 3 to $11 \mathrm{mM}$ glucose triggers pronounced $\mathrm{PIP}_{3}$ 
oscillations. (B) The glucose effect on $\mathrm{PIP}_{3}$ depends on feedback from secreted insulin and is consequently prevented by blocking secretion with the hyperpolarizing agent diazoxide. 


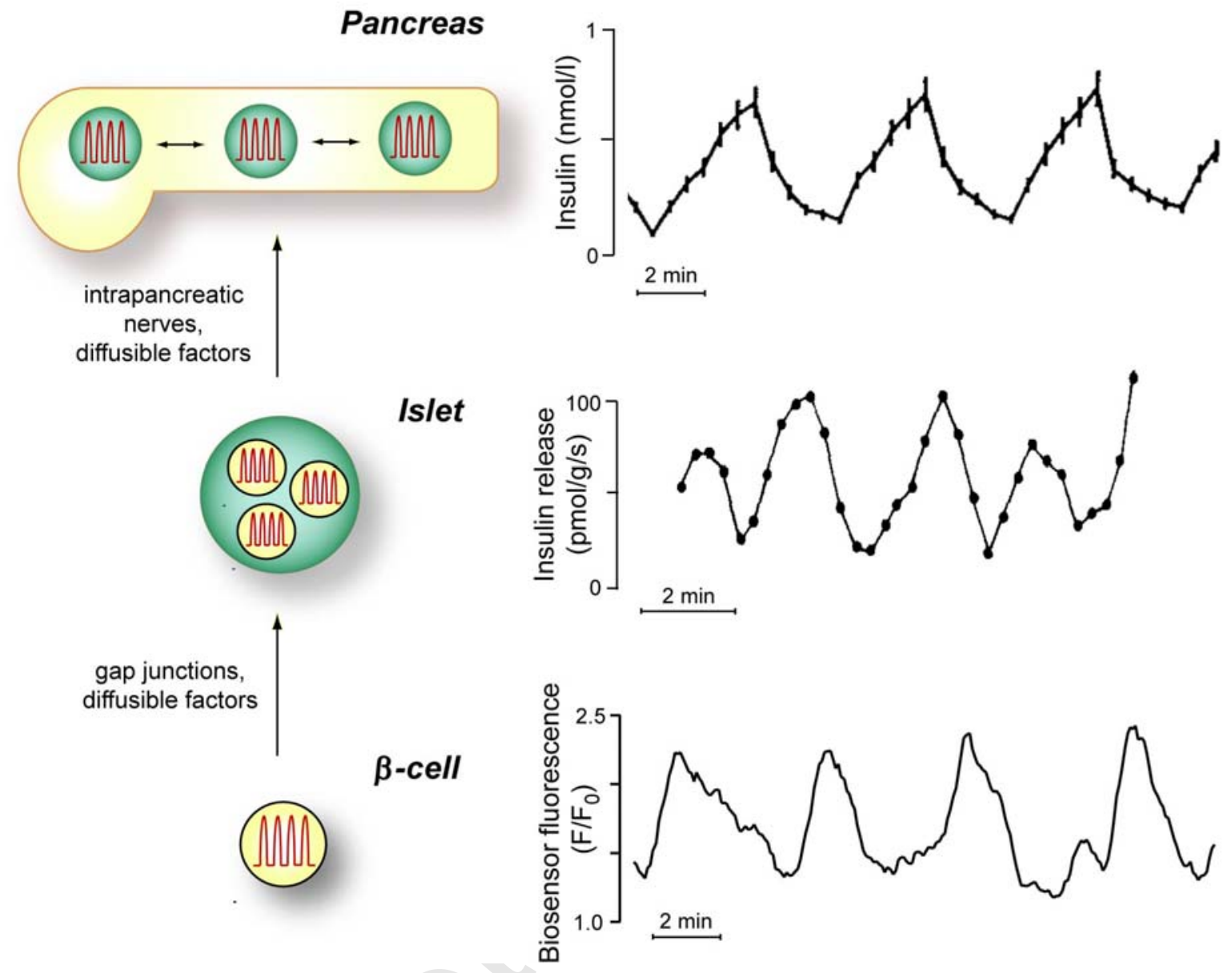

FIG. 1 
A

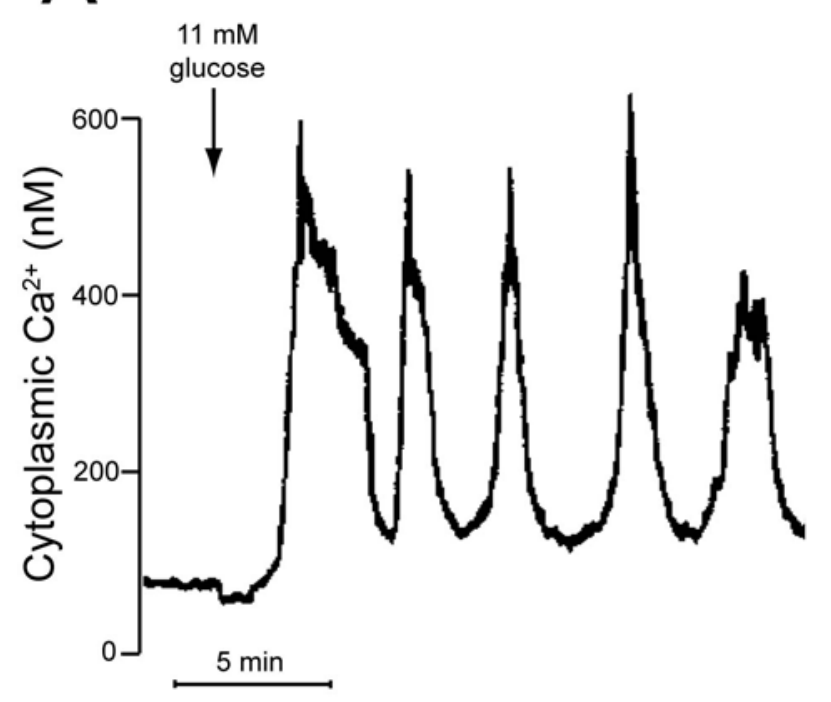

B

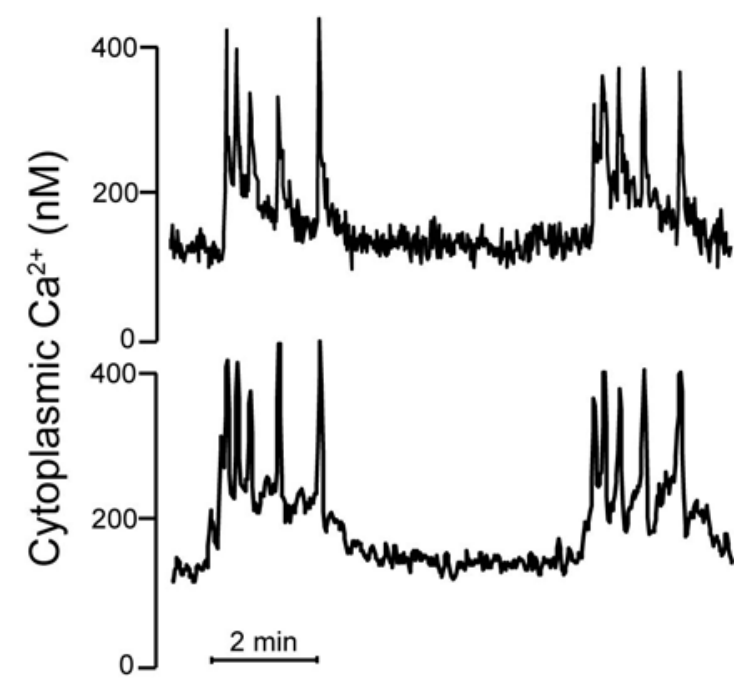

C

D

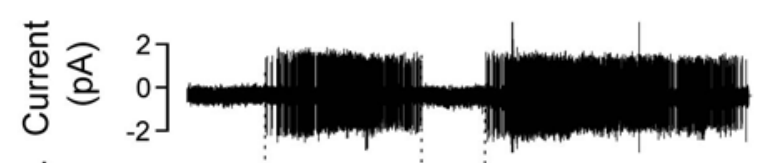

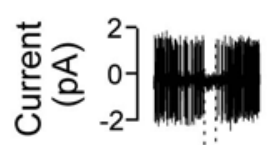
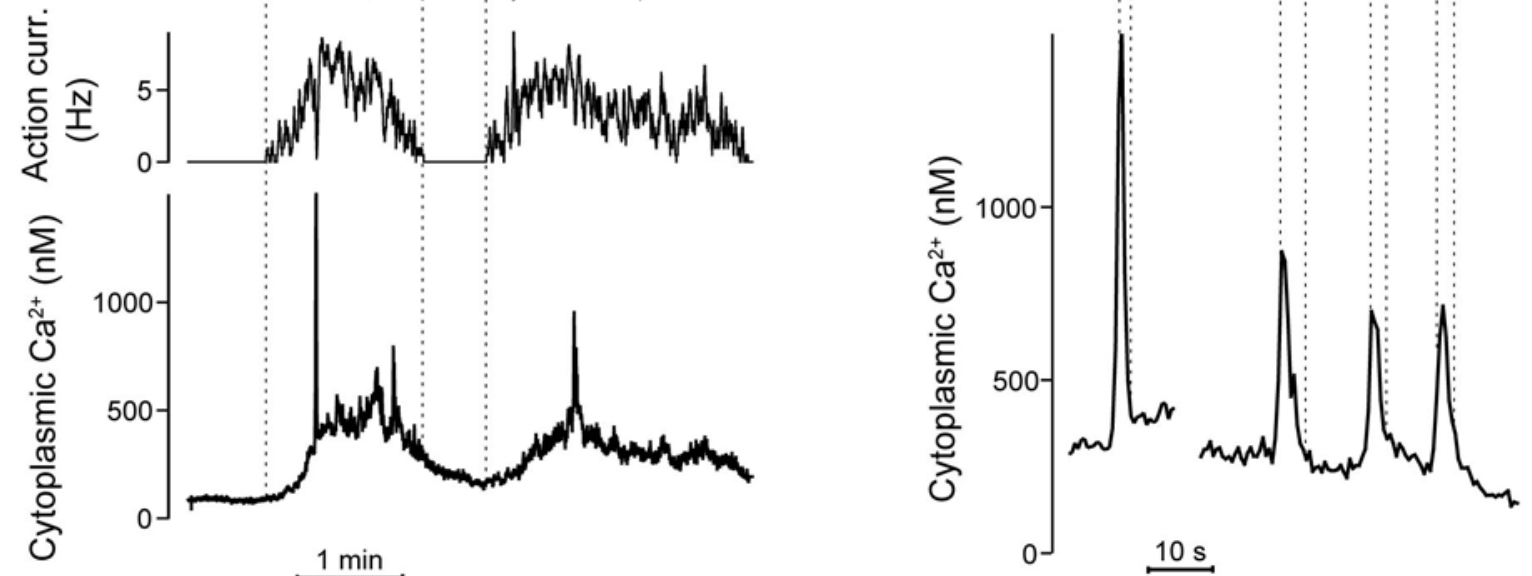

FIG. 2 
A

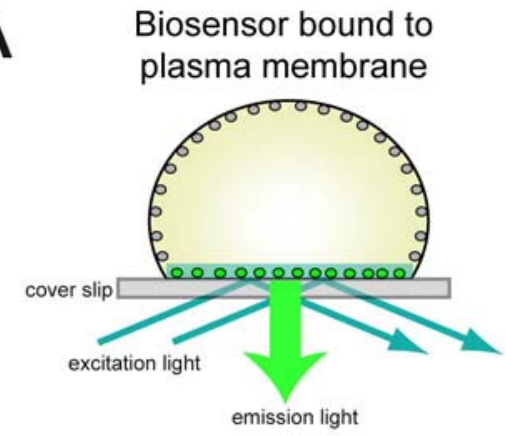

Bisensor in cytoplasm

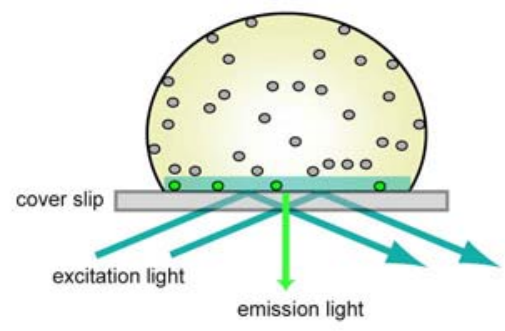

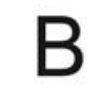

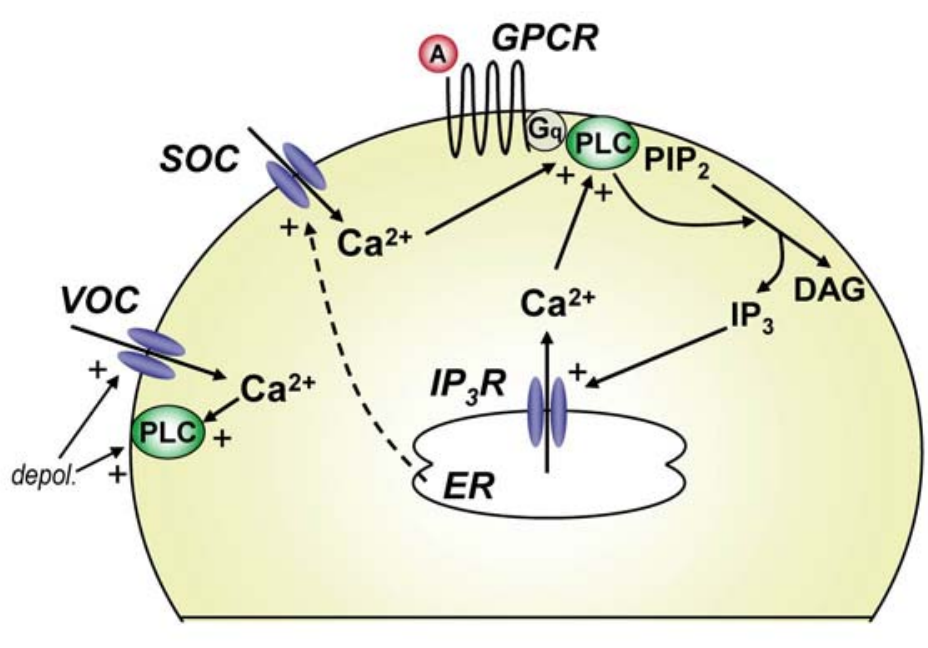

C

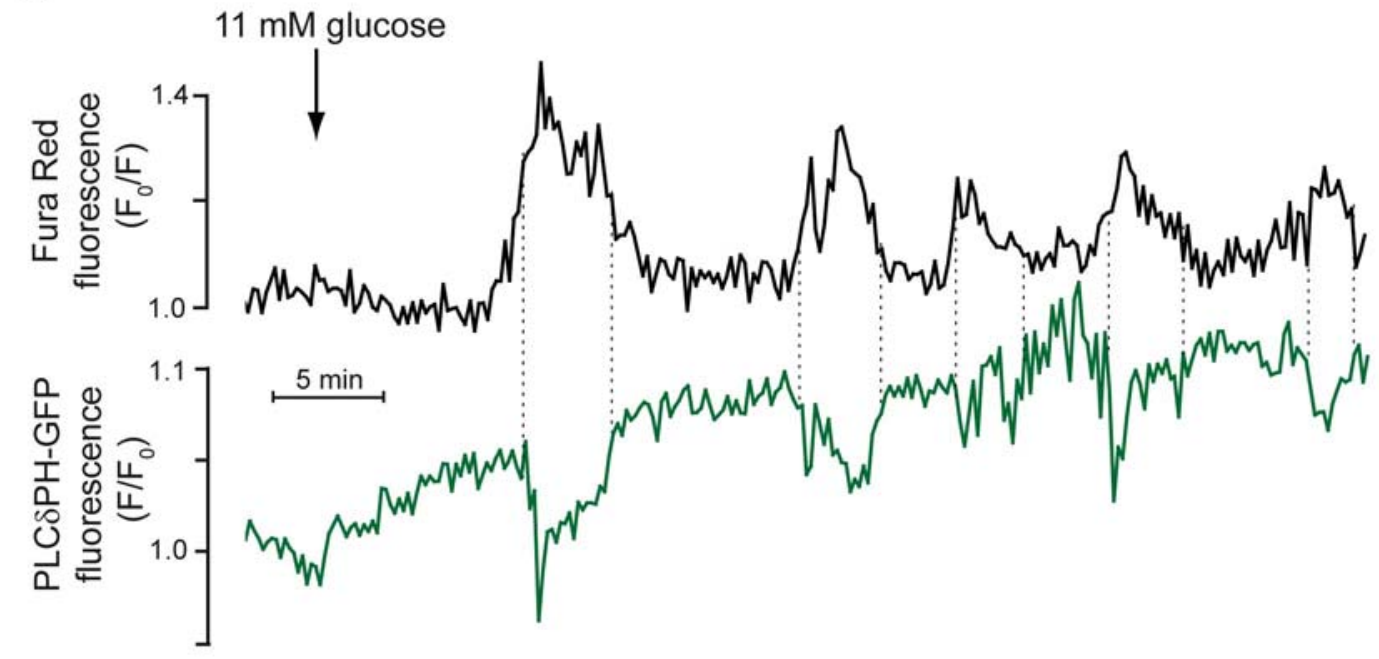

D

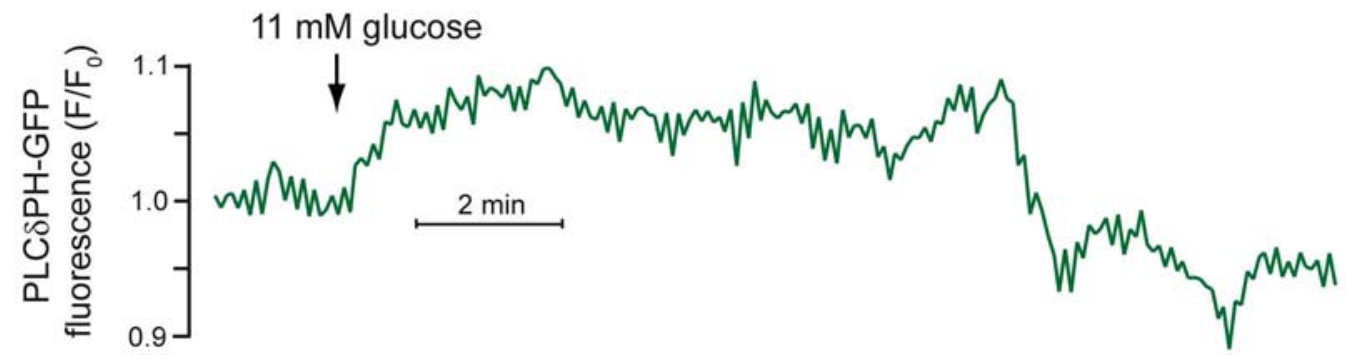

FIG. 3 
A

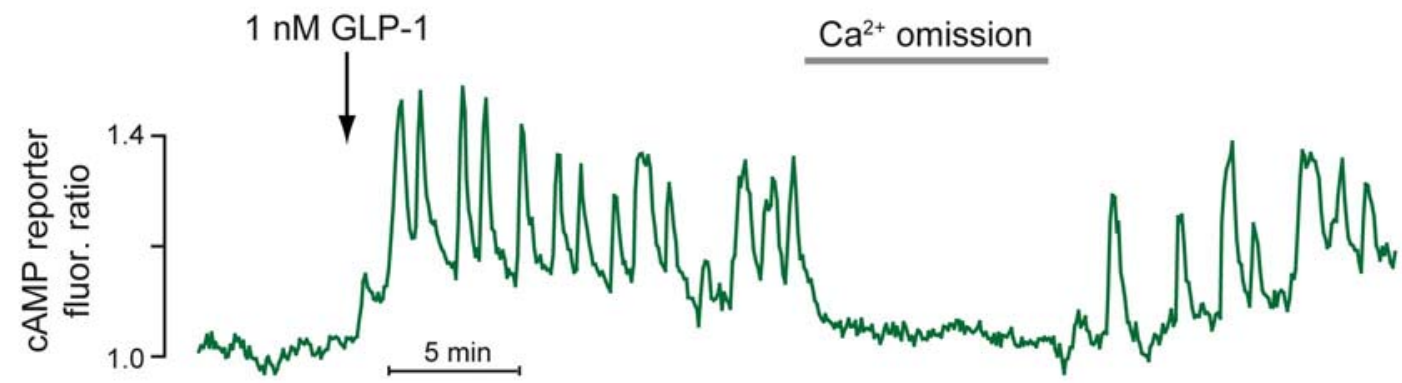

B

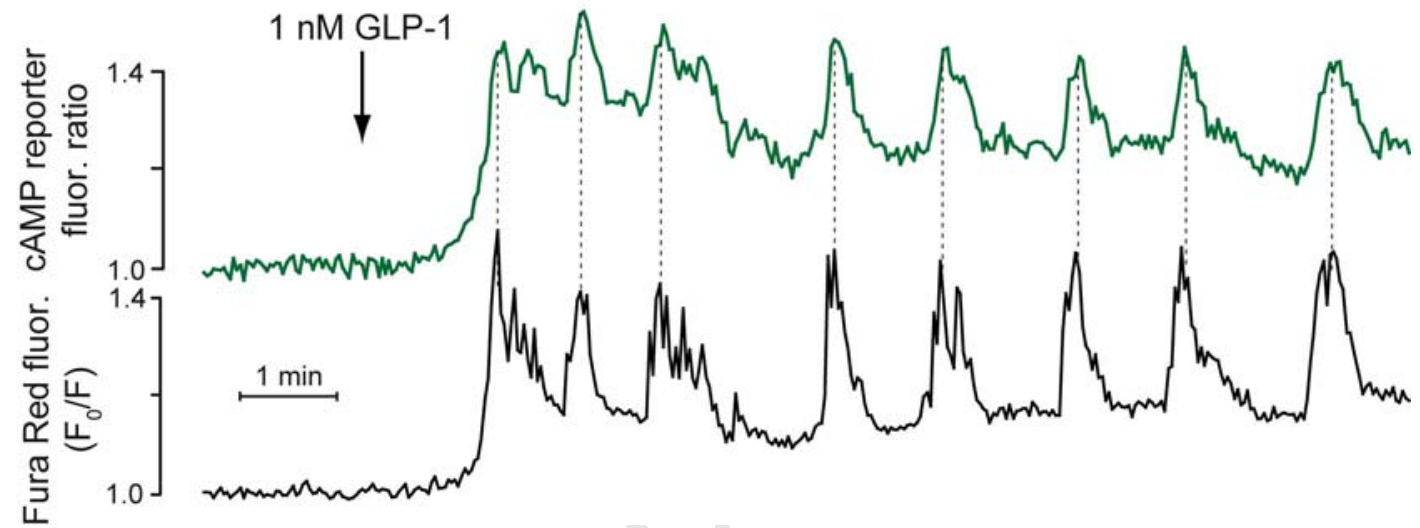

FIG. 4 


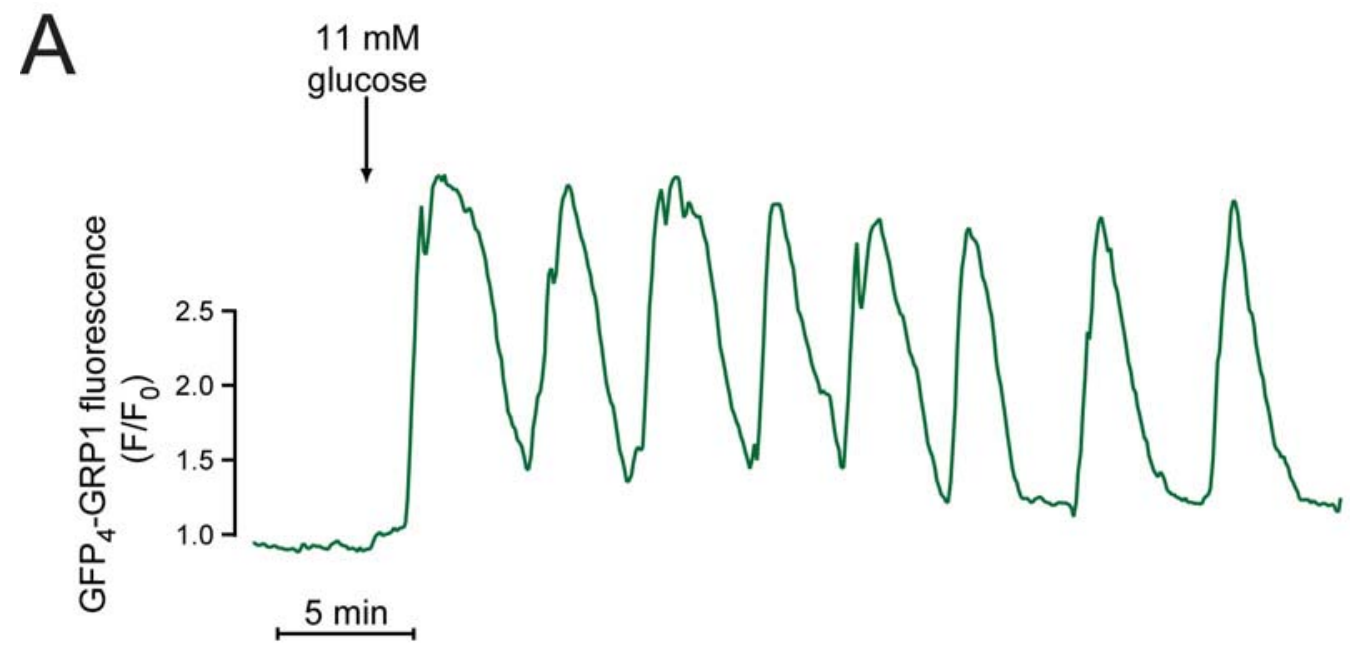

B

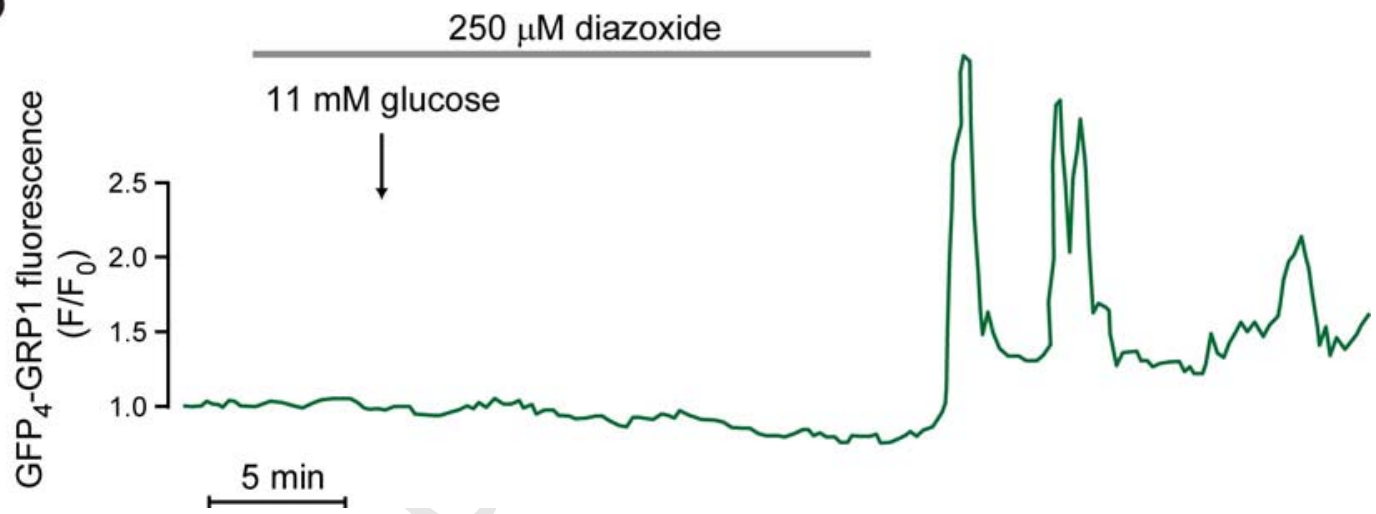

FIG. 5 